\title{
Analysis of the effectiveness of landscape protection in the Liancheng National Nature Reserve, Gansu, China
}

Zhihao Huang ( $\sim$ huangzhihao@bjfu.edu.cn )

Beijing Forestry University https://orcid.org/0000-0003-4427-1470

\section{Yangjing Peng}

Beijing Forestry University

\section{Ruifeng Wang}

Beijing Forestry University

\section{Guofa Cui}

Beijing Forestry University

\section{Nachuan Lu}

Twenty First Century Aerospace Technology Co.,Ltd.

\section{Bo Zhang}

Twenty First Century Aerispace Technology Co.,Ltd

\section{Research}

Keywords: Landscape pattern, Human interference, Driving factors, Effectiveness of landscape protection, Liancheng National Nature Reserve

Posted Date: December 28th, 2020

DOl: https://doi.org/10.21203/rs.3.rs-135015/v1

License: (c) (i) This work is licensed under a Creative Commons Attribution 4.0 International License. Read Full License 
1 Analysis of the effectiveness of landscape protection in the Liancheng National Nature 2 Reserve, Gansu, China

3 Zhihao Huang ${ }^{1}$, Yangjing Peng ${ }^{1}$, Ruifeng Wang ${ }^{1}$, Guofa Cui ${ }^{1 *}$, Bo Zhang ${ }^{2}$, Nachuan Lu $^{2}$

4 *Correspondence: fa6716@163.com

$5 \quad{ }^{1}$ School of Ecology and Nature Conservation, Beijing Forestry University, Beijing 100083, China

$6 \quad 2$ Twenty-first Century Space Technology Co.

7 Abstract

$8 \quad$ Background

9 The rapid assessment of the effectiveness of landscape protection in nature reserves is of great significance 10 for the scientific formulation of protection and management countermeasures for nature reserves and is also 11 an urgent problem to be solved for the construction and management of nature reserves in China. Using high12 resolution remote sensing image data, this study analyzes the landscape dynamics in the Liancheng National

13 Nature Reserve (LNNR) and their driving factors since the reserve's promotion to the national level in 2005, 14 and proposes a comprehensive evaluation method for the effectiveness of landscape protection in protected 15 areas based on the Landscape Transfer Index (LTI), Protected Landscape Integrity Index (PLII), and Interfered 16 Landscape Sprawl Index (ILSI).

17 Results

18 Between 2006 and 2019, the area of protected landscape - namely woodland, grassland, and water-in the LNNR decreased, while the area of interfered landscape such as residential land, industrial and mining land, and water conservancy facility land increased. The LTI was -0.14 , and among the driving factors, the development of industry and mining, land use by indigenous inhabitants, and the development of the transport industry made the highest contribution to the landscape transfer tendency, being respectively $34.79 \%, 28.98 \%$, and $17.30 \%$. The PLII decreased from 82.7 to 68.7 and the ILSI increased from 26.61 to 26.68 .

\section{Conclusion}

The effectiveness of landscape protection in the LNNR is low. Between 2006 and 2019, the overall quality of the landscape slightly decreased, the spatial pattern of the protected landscape became more fragmented, and the degree of human interference in the landscape increased; however, the scope of influence of human interference did not change significantly. These changes were mainly due to industrial and mining exploitation, land use by indigenous inhabitants, and road construction. However, despite the insignificant nature of these changes, they still require attention and timely remedial measures. The methodology proposed in this study may be applicable to the rapid assessment of the effectiveness of landscape conservation in various types of 
nature conservation sites around the world.

\section{$33 \quad$ Keywords}

34 Landscape pattern, Human interference, Driving factors, Effectiveness of landscape protection, Liancheng 35 National Nature Reserve

\section{$36 \quad$ Introduction}

Natural habitat loss and fragmentation are important threats to global biodiversity conservation (Chase et al. 2020; Sala et al. 2000). Studies have shown that the establishment of protected areas (PAs) can effectively curb the destruction of natural ecosystems, and this approach is a major component of biodiversity conservation ( $\mathrm{Li}$ et al. 2020; Ma et al. 2012; Tang et al. 2011). In 2019, there were 261,200 PAs of various types in the world, covering $15.3 \%$ of the global terrestrial and freshwater environment (Maxwell et al. 2020). Analyzing landscape changes in PAs is an intuitive way to monitor and evaluate such areas. Scholars classify the landscapes in PAs into two categories according to their attributes, namely protected and interfered landscape(Zhang et al. 2014; Lindenmayer 2006; Chinese State Forestry Bureau 2008). The former mainly refers to natural landscapes but also includes some human-made landscapes that are beneficial to wildlife; the latter refers to the types of human-made landscape that cause interference and damage to natural ecosystems and wildlife habitats (Rovero et al. 2017; Richard et al. 2011; Lin et al. 2017). It is generally accepted that PAs are effective for the conservation of natural habitats (Rosas et al. 2017; Guo et al. 2017). However, some scholars have argued that the loss of wildlife habitat in some PAs due to increased anthropogenic interference has still not been effectively curtailed, questioning the conservation effectiveness of nature reserves (Fuller et al. 2010; Guadilla-Sáez et al. 2019). Therefore, it is highly necessary to scientifically assess the conservation effectiveness of PAs by monitoring the dynamic changes in the protected landscape.

In China, there are 11,800,000 PAs of various types, covering a total area of more than 1.8 million $\mathrm{km}^{2}$ (Chen 2019). Among them, nature reserves occupy the largest area among the various types of PAs and are of fundamental importance for ecological conservation (Zhao et al. 2020). There are a total of 2750 nature reserves in China, covering a combined area of 1.47 million $\mathrm{km}^{2}$, accounting for $15 \%$ of China's land area; of these, 474 are state-level nature reserves covering a total area of $980,000 \mathrm{~km}^{2}$, accounting for $10 \%$ of China's land area (Wang 2019). Anthropogenic activities are prevalent in these national nature reserves; as of 2015, anthropogenic activities were present in 446 national nature reserves in China (Liu et al. 2020), and the level of such activities is expected to continue to increase as the population increases (Wittemyer et al. 2008). Furthermore, a comprehensive quantitative assessment of the landscape protection effectiveness of nature 
reserves in China has not been carried out, and how to scientifically and rapidly assess the landscape protection effectiveness of nature reserves following their establishment is an urgent problem for the construction and management of nature reserves.

In recent years, scholars in China and abroad have conducted a large number of studies on the dynamic changes of regional landscapes and their driving factors using a combination of remote sensing and GIS, based on theories related to landscape ecology (Cao et al. 2015; He et al. 2019; Su et al. 2011; Zheng et al. 2017). Most of these studies were conducted at large spatial scales using moderate-resolution $(\geq 30 \mathrm{~m})$ satellite image data. In nature reserves, under strict control measures, the landscape generally does not change to a large extent; however, smaller-scale anthropogenic activities that lead to landscape changes are common, such as the construction of water conservancy facilities, residential land use, and tourism service facilities. It is difficult to identify these activities with medium-resolution satellite imagery. With the development of remote sensing and geographic information systems, high-resolution satellite imagery has enabled researchers to accurately identify landscape changes in nature reserves at smaller scales (Cong et al. 2019; Cui et al. 2014; Song et al. 2016), providing the possibility to accurately assess the effectiveness of landscape protection in nature reserves.

Scholars in China have explored methods to assess the effectiveness of conservation in nature reserves from different aspects such as landscape, vegetation, plants, and animals (Guan et al. 2012; Liu et al. 2016; Jin et al. 2015; Xin et al. 2015). Additionally, based on the research results, forestry industry standards were issued (Chinese State Forestry Bureau 2014), providing a theoretical basis for research on the conservation effectiveness of nature reserves at the landscape level. However, research by Chinese and foreign scholars on the conservation effectiveness of nature reserves at the landscape level has mainly focused on changes in landscape dynamics, the impacts of human interference, and the effectiveness of habitat quality protection (Broadbent et al. 2012; Mehring and Stoll-Kleemann 2011; Guo et al. 2017; Long et al. 2014; Niu et al. 2003; Lin et al. 2019). These studies evaluated the conservation effectiveness of different types of nature reserves from different perspectives; however, a fast, effective, and universal method to evaluate the landscape protection effectiveness of nature reserves is lacking.

This study takes the Liancheng National Nature Reserve (LNNR) as the study area and uses highresolution remote sensing image data from 2006 and 2019 to analyze the landscape change trend and its drivers from the perspective of landscape type change since the nature reserve was promoted to a national nature reserve in 2005; moreover, it proposes the use of the Protected Landscape Integrity Index (PLII) and the Interfered Landscape Sprawl Index (ILSI) to attempt to quantify the integrity of protected landscape and the 
influence range of human disturbance from the perspective of the landscape spatial distribution pattern. These methods were used to comprehensively evaluate the effectiveness of landscape protection in the LNNR since its promotion to a national nature reserve. The main objectives of this study are as follows: (1) To propose a method to rapidly assess the effectiveness of landscape protection in nature reserves; (2) to evaluate the effectiveness of landscape protection in the LNNR using this method; and (3) to propose countermeasures and recommendations for landscape protection management in the LNNR.

\section{Data sources and research methods}

\section{Overview of the study area}

The LNNR is located in the arid northwest of China, in Yongdeng County, Lanzhou City, and in the Tianzhu Tibetan Autonomous County, Wuwei City. It was established as a provincial nature reserve in 2001 and promoted to a national nature reserve in 2005. The geographical coordinates of the reserve are

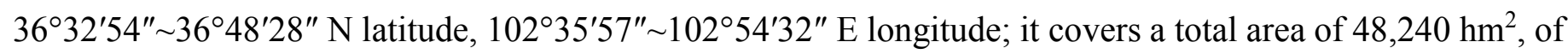
which, $14,440 \mathrm{hm}^{2}(29.93 \%)$ is the core zone, $13,333 \mathrm{hm}^{2}(27.64 \%)$ is the buffer zone, and $20,467 \mathrm{hm}^{2}$ $(42.43 \%)$ is the experimental zone. The LNNR is located in the middle and lower reaches of the Huangshui River, a major tributary of the Yellow River. The LNNR is a forest ecosystem type nature reserve; the main object of protection is the Sabina przewalskii and Picea crassifolia forest ecosystem and the habitat of nationally protected wild animals and plants. The LNNR has a wide variety of vegetation, which can be divided into six vegetation types, 17 formation groups, and 28 formations, providing a good habitat for wild animals and plants to survive and reproduce. A survey of the LNNR found vascular plants from 91 families, 403 genera, and 1283 species, and terrestrial vertebrates from 24 orders, 66 families, and 220 species(Wang 2008). Its rich biodiversity and many rare and endangered species make the LNNR a rare-species gene pool, especially in the Loess Plateau region. Furthermore, the large areas of primeval forest in the LNNR, which are composed of S. przewalskii, Picea wilsonii, and P. crassifolia, make it an important forest and water conservation area in the upper reaches of the Yellow River. The LNNR is not only regionally representative but also has high conservation and scientific research value. As of 2019, there were 30,695 community residents living within the LNNR, distributed among 10 administrative villages and one community in two townships, mainly in the experimental zone of the reserve. These communities are subject to frequent human activities, which greatly threaten the protection and management work of the reserve. 


\section{Data sources}

Two sets of remote sensing images of the study area were collected, one acquired in 2006 (resolution: $2.5 \mathrm{~m}$ ) and the other in 2019 (resolution: $2 \mathrm{~m}$ ). Socio-economic data for the LNNR were obtained from the survey statistics of the Chinese Nature Reserve Authority.

\section{Data processing}

\section{Remote sensing image processing and landscape classification}

Using the ENVI 5.1 software (L3Harris Geospatial, Boulder, Colorado, USA), the two image series were processed with geometric correction, multi-band blending, panchromatic sharpening and cropping. The protected area was divided into 10 primary landscape types and 21 secondary landscape types (Table 2) based on the Chinese Land Use Classification Standard (GB/T 21010-2017). The accuracy of the decomposition results was assessed using a field survey, and the attribute accuracy and boundary accuracy of the decomposition results for 2006 and 2019 were found to be greater than 97\% (Table 1), which meets the accuracy requirements (Cong et al. 2019; Cui et al. 2014; Song et al. 2016).

Table 1 The results of the accuracy analysis of the landscape classification in the Liancheng National Nature Reserve (LNNR)

\begin{tabular}{llllllll}
\hline Remote sensing & Total & Number of & Sampling & Number of & Attribute & Number of & Boundary \\
image acquisition & number of & samples & rate & correct & accuracy & correct & accuracy \\
\hline
\end{tabular}




\begin{tabular}{|c|c|c|c|c|c|c|c|}
\hline year & patches & & & attributes & & boundaries & \\
\hline 2006 & 1901 & 471 & $25 \%$ & 464 & $98.51 \%$ & 468 & $99.36 \%$ \\
\hline 2019 & 1971 & 381 & $19 \%$ & 372 & $97.64 \%$ & 370 & $97.11 \%$ \\
\hline
\end{tabular}

The 21 secondary landscape types were classified into protected, interfered, and neutral landscapes based on the attributes of the land use/land cover (LULC) types (Table 2): protected landscapes include natural forest, artificial forest, shrub forest, grasslands, and river water surface; interfered landscape include agricultural land, mining land, industrial land, roads, hydraulic architecture, urban residential land, detached houses, rural residential land and other construction land. Neutral landscape includes bare land and bare gravel land. Ecological levels were assigned to the different types of landscapes using the golden divide method (Table 2), in which threshold values of 0.62 and 0.38 were used to divide the given interval. A higher assigned value indicates a higher ecological level. Interfered landscapes have negative values, and larger absolute values indicate a higher level of anthropogenic interference. Neutral landscapes are assigned a value of 0 (Zhang et 148 al. 2014).

Table 2 The assigned landscape types and ecological levels in the LNNR

\begin{tabular}{|c|c|c|c|c|c|c|c|}
\hline $\begin{array}{c}\text { Primary } \\
\text { landscape type }\end{array}$ & $\begin{array}{c}\text { Secondary } \\
\text { landscape type }\end{array}$ & $\begin{array}{c}\text { Landscape } \\
\text { classificatio } \\
\text { n }\end{array}$ & Ecological level & $\begin{array}{c}\text { Primary } \\
\text { landscape type }\end{array}$ & $\begin{array}{c}\text { Secondary } \\
\text { landscape type }\end{array}$ & $\begin{array}{c}\text { Landscape } \\
\text { classification }\end{array}$ & Ecological level \\
\hline \multirow{3}{*}{ Woodland } & Shrub forest & $\begin{array}{l}\text { Protected } \\
\text { landscape }\end{array}$ & 0.62 & \multirow{2}{*}{ Bare land } & Bare land & $\begin{array}{l}\text { Neutral } \\
\text { landscape }\end{array}$ & 0 \\
\hline & Artificial forest & $\begin{array}{l}\text { Protected } \\
\text { landscape }\end{array}$ & 0.38 & & Bare gravel land & $\begin{array}{l}\text { Neutral } \\
\text { landscape }\end{array}$ & 0 \\
\hline & Natural forest & $\begin{array}{l}\text { Protected } \\
\text { landscape }\end{array}$ & 1 & $\begin{array}{c}\text { Other } \\
\text { construction } \\
\text { land }\end{array}$ & $\begin{array}{c}\text { Other } \\
\text { construction land }\end{array}$ & $\begin{array}{l}\text { Interfered } \\
\text { landscape }\end{array}$ & -0.62 \\
\hline Grassland & Grassland & $\begin{array}{l}\text { Protected } \\
\text { landscape }\end{array}$ & 0.62 & $\begin{array}{c}\text { Water } \\
\text { conservancy }\end{array}$ & Ditches & $\begin{array}{l}\text { Interfered } \\
\text { landscape }\end{array}$ & -0.62 \\
\hline \multirow{2}{*}{ Cropland } & Cultivated land & $\begin{array}{l}\text { Interfered } \\
\text { landscape }\end{array}$ & -0.38 & facility land & $\begin{array}{l}\text { Hydraulic } \\
\text { architecture }\end{array}$ & $\begin{array}{l}\text { Interfered } \\
\text { landscape }\end{array}$ & -1 \\
\hline & $\begin{array}{c}\text { Agricultural facility } \\
\text { land }\end{array}$ & $\begin{array}{l}\text { Interfered } \\
\text { landscape }\end{array}$ & -0.62 & \multirow{3}{*}{ Water } & $\begin{array}{c}\text { River water } \\
\text { surface }\end{array}$ & $\begin{array}{l}\text { Protected } \\
\text { landscape }\end{array}$ & 1 \\
\hline \multirow{2}{*}{$\begin{array}{l}\text { Industrial and } \\
\text { mining land }\end{array}$} & Mining land & $\begin{array}{l}\text { Interfered } \\
\text { landscape }\end{array}$ & -1 & & Ponds & $\begin{array}{l}\text { Interfered } \\
\text { landscape }\end{array}$ & -0.38 \\
\hline & $\begin{array}{l}\text { Industry and } \\
\text { storage land }\end{array}$ & $\begin{array}{l}\text { Interfered } \\
\text { landscape }\end{array}$ & -1 & & $\begin{array}{c}\text { Urban residential } \\
\text { land }\end{array}$ & $\begin{array}{l}\text { Interfered } \\
\text { landscape }\end{array}$ & -0.62 \\
\hline \multirow[t]{2}{*}{$\begin{array}{c}\text { Traffic facility } \\
\text { land }\end{array}$} & Highways & $\begin{array}{l}\text { Interfered } \\
\text { landscape } \\
\text { Interfered } \\
\text { landscape }\end{array}$ & -1 & \multirow[t]{2}{*}{ Residential land } & $\begin{array}{l}\text { Detached house } \\
\text { Rural residential } \\
\text { land }\end{array}$ & $\begin{array}{l}\text { Interfered } \\
\text { landscape } \\
\text { Interfered } \\
\text { landscape }\end{array}$ & -0.62 \\
\hline & Railway land & $\begin{array}{l}\text { Interfered } \\
\text { landscape }\end{array}$ & -1 & & & & \\
\hline
\end{tabular}




\section{Landscape transfer matrix}

The intersection module of ArcGIS was used to calculate the geometric intersection in 2006 and 2019. Landscape type vector maps were used to statistically derive the area change of each landscape type between different periods and generate the landscape transfer matrix. To clearly demonstrate the changes in landscape pattern, the networkD3 package for $\mathrm{R}$ was used to draw the landscape transfer matrix Sankey diagram, and the area change rate of each landscape type was also calculated.

\section{Landscape Transfer Index}

The Landscape Transfer Index (LTI) can directly reflect the overall trend of landscape type change. According to the ecological level assigned to each landscape type, the LTI of the LNNR was calculated based on the landscape transfer matrix using the following formula:

$$
I_{T}=\frac{\sum_{\mathrm{i}=1}^{\mathrm{m}} \sum_{\mathrm{j}=1}^{\mathrm{n}} S_{i \rightarrow \mathrm{j}}\left(D_{j}-D_{i}\right)}{S_{T}} \times 100
$$

where $I_{T}$ is the landscape transfer index; $m$ is the number of landscape types in the previous period; $\mathrm{n}$ is the number of landscape types in the current period; $S_{i \rightarrow \mathrm{j}}$ is the area in which landscape type $i$ was converted to landscape type $j ; S_{T}$ is the total area of the nature reserve; and $D_{i}$ and $D_{j}$ denote the assigned ecological levels of landscape types $i$ and $j$, respectively.

The LTI has values between -200 and 200; positive values indicate that the landscape and ecological conditions of the area have improved and negative values indicate that they have deteriorated, with larger absolute values indicating greater change and vice versa.

\section{Protected Landscape Integrity Index}

In this study, the fragmentation index and the edge effect index were used to comprehensively characterize the degree of integrity of the protected landscape in the LNNR using the following formulae:

$$
\begin{gathered}
I_{F}=1-\sum_{j=1}^{n}\left(\frac{S_{j}}{\sum_{j=1}^{n} S_{j}}\right)^{2} \\
I_{E}=\sum_{j=1}^{n}\left[\frac{S_{j}}{\sum_{j=1}^{n} S_{j}} \cdot \frac{2 \lg \left(0.25 P_{j}\right)}{\lg S_{j}}\right] \\
I_{I}=\sqrt[3]{\frac{\sum_{j=1}^{n} S_{j}}{S_{T}} \cdot\left(1-I_{F}\right) \cdot\left(2-I_{E}\right) \times 100}
\end{gathered}
$$

where $I_{F}$ is the fragmentation index of the protected landscape, reflecting the overall fragmentation of all protected landscapes, and has values of between 0 and $1 ; S_{j}$ is the area of the jth protected landscape mosaic 
patch; $n$ is the total number of protected landscape mosaic patches; $I_{E}$ is the edge effect index of the protected landscape; $P_{j}$ is the perimeter of the jth protected landscape mosaic patch; $I_{I}$ is the integrity index of the protected landscape; and $S_{T}$ is the total area of the LNNR.

The value of $I_{I}$ ranges from 0 to 100 , with larger values indicating less fragmentation of the protected landscape mosaic, weaker edge-effect strength, and greater landscape integrity, and vice versa.

\section{Interfered Landscape Sprawl Index}

The Interfered Landscape Sprawl Index $\left(I_{S}\right)$ was used to characterize the degree of dispersion of the spatial distribution of the interfered landscape and the intensity of edge effects in the LNNR in order to evaluate the extent of anthropogenic interference in the reserve. This index was calculated according to the following formulas:

$$
\begin{gathered}
P_{i j}=\frac{E_{i j}}{E} \\
I_{S}=-\frac{\sum_{i=1}^{m} \sum_{j=1}^{n} P_{i j} \ln P_{i j}}{\ln (\mathrm{m}+\mathrm{n})} \times 100
\end{gathered}
$$

where $P_{i j}$ is the ratio of the common boundary length $\left(E_{i j}\right)$ between the $i$-th interfered landscape mosaic patch and the $j$-th mosaic patch for all other types of landscape (including protected and neutral landscapes) to the total common boundary length $(E)$ between all interfered landscape mosaic patches and other landscape mosaic patches; $\mathrm{m}$ is the total number of interfered landscape mosaic patches; and $n$ the total number of mosaic patches for all other types of landscape.

The value of $I_{S}$ ranges from 0 to 100 ; the larger the value, the more dispersed the distribution of interfered landscape, the greater the edge effect, and the greater the extent of anthropogenic interference.

\section{Classification of drivers of landscape change}

To analyze the causes of landscape changes in the LNNR, the landscape change patches in different periods were extracted using the ArcGIS topological analysis module. According to the actual situation of the LNNR obtained through past field investigation and image processing, the direct driving factors of each landscape patch change were qualitatively classified and the direct driving factors leading to landscape change were classified into nine categories (Table 3 ).

\begin{tabular}{|c|c|c|}
\hline Driving factor & Description & Main conversion type \\
\hline Natural disturbance & $\begin{array}{l}\text { Landscape changes as a direct result of purely natural } \\
\text { disturbances (e.g., landslides) }\end{array}$ & Woodland $\rightarrow$ Bare land \\
\hline \multirow{2}{*}{ Land use by indigenous inhabitants } & Landscape changes as a direct result of new housing, & Bare land $\rightarrow$ Cropland \\
\hline & agricultural reclamation, etc. & Bare land $\rightarrow$ Residential land \\
\hline
\end{tabular}

Table 3 The results for the direct drivers of landscape patch changes in the LNNR between 2006 and 2019 
Population displacement

Development of industry and mining

\author{
Development of the water and \\ hydropower industry
}

Development of agricultural industry

Development of transport industry

Development of tourism industry

Ecological restoration
Landscape changes as a direct result of house demolitions, abandonment of cultivated land, etc.

Landscape changes as a direct result of the construction of industrial and mining facilities, (e.g., ore mining)

Landscape changes due to the construction of dams, hydropower plants, and other hydroelectric facilities

Landscape changes as a direct result of the construction of agricultural facilities (e.g., farms and grow houses)

Landscape changes as a direct result of road construction, road hardening, etc.

Landscape changes as a direct result of the construction of amusement parks, observation decks, and other tourism services

Landscape changes as a direct result of conservation works (e.g., ecological restoration) carried out by authorities in the protected area
Residential land $\rightarrow$ Bare land

Cropland $\rightarrow$ Bare land / Grassland

Woodland $\rightarrow$ Bare land

Bare land $\rightarrow$ Industrial and mining land

Water $\rightarrow$ Water conservancy facility land / Bare land

Bare land / Cropland $\rightarrow$ Water

Cropland $\rightarrow$ Other construction land

Woodland / Bare land $\rightarrow$ Traffic facility land

Woodland $\rightarrow$ Bare land / Other construction land

Bare land $\rightarrow$ Woodland 
Results

\section{Changes in landscape area}

The LNNR has three main types of protected landscapes (forest land, grassland, and water) and six types of interfered land (cropland, residential land, traffic facility land, water conservancy facility land, industrial and mining land, and other construction land). The results show that, between 2006 and 2019, the total area of protected landscapes in the reserve decreased from $42,505.59 \mathrm{hm}^{2}(88.25 \%$ of the reserve's total area) to $42,456.16 \mathrm{hm}^{2}(88.15 \%)$ (Table 4). Woodland occupies the largest area among all landscape types in the LNNR, and its area decreased from $41,325.16 \mathrm{hm}^{2}\left(85.80 \%\right.$ of the reserve's total area) in 2006 to $41,292.32 \mathrm{hm}^{2}$ $(85.73 \%)$ in 2019 , a decrease of $32.84 \mathrm{hm}^{2}$. In the same period, the grassland area decreased from $771.03 \mathrm{hm}^{2}$ ( $1.6 \%$ of the reserve's total area) to $760.86 \mathrm{hm}^{2}(1.58 \%)$, while the water area decreased from $409.4 \mathrm{hm}^{2}(0.85 \%$ of the reserve's total area) to $402.98 \mathrm{hm}^{2}(0.84 \%)$. That is, between 2006 and 2019, the areas of all types of protected landscapes in the reserve decreased slightly, and the annual rate of change in area was small (Table 4). In the same period, the area of interfered landscape in the reserve increased from $5526.36 \mathrm{hm}^{2}(11.47 \%$ of the reserve's total area) to $5546.71 \mathrm{hm}^{2}(11.52 \%)$. Of the various types of interfered landscape in the LNNR, cropland accounts for the largest area, and decreased from $4808.01 \mathrm{hm}^{2}(9.98 \%$ of the reserve's total area) in 2006 to $4773.51 \mathrm{hm}^{2}(9.91 \%)$ in 2019 . During the same period, all other types of interfered landscape also increased in area to varying degrees, with residential landscape experiencing the largest percentage of area expansion of any type of interfered land, increasing continuously from $462.38 \mathrm{hm}^{2}$ in 2006 to $488.45 \mathrm{hm}^{2}$ in 2019. Water facility landscape experienced the fastest area expansion of any interfered landscape type, with a mean annual change in area of 5.54\%. 

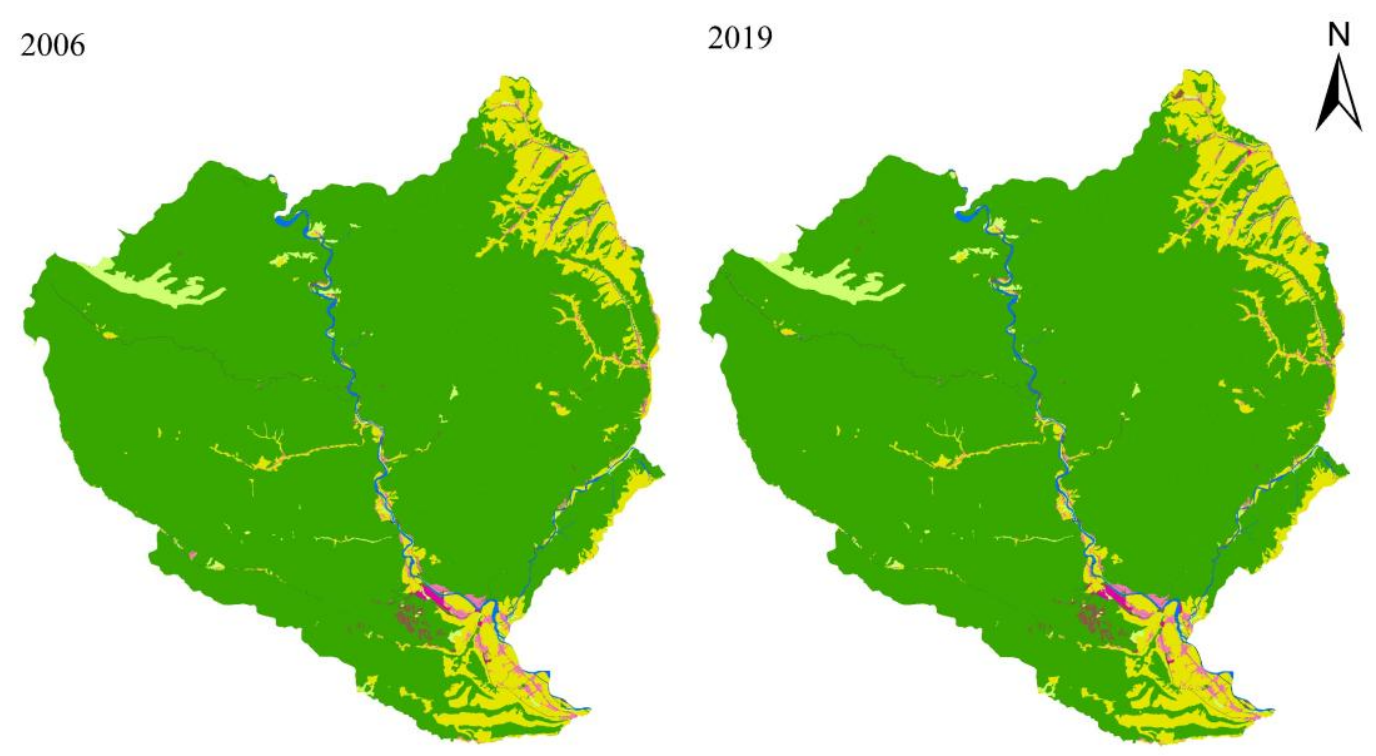

Legend

Table 4 Changes of landscape use types in the LNNR between 2006 and 2019

\begin{tabular}{|c|c|c|c|c|c|}
\hline \multirow[b]{2}{*}{ Landscape type } & \multicolumn{2}{|c|}{2006} & \multicolumn{2}{|c|}{2019} & \multirow{2}{*}{$\begin{array}{c}\text { Area variation } \\
\text { ratio } \\
\left(\% \cdot \mathrm{a}^{-1}\right)\end{array}$} \\
\hline & Area $\left(\mathrm{hm}^{2}\right)$ & $\begin{array}{c}\text { Proportion* } \\
(\%)\end{array}$ & $\begin{array}{l}\text { Area } \\
\left(\mathrm{hm}^{2}\right)\end{array}$ & $\begin{array}{c}\text { Proportion* } \\
(\%)\end{array}$ & \\
\hline Woodland & $41,325.16$ & 85.80 & $41,292.32$ & 85.73 & -0.01 \\
\hline Grassland & 771.03 & 1.60 & 760.86 & 1.58 & -0.10 \\
\hline Water & 409.4 & 0.85 & 402.98 & 0.84 & -0.12 \\
\hline Bare land & 132.84 & 0.28 & 161.92 & 0.34 & 1.68 \\
\hline Cultivated land & 4808.01 & 9.98 & 4773.51 & 9.91 & -0.06 \\
\hline Residential land & 462.38 & 0.96 & 488.45 & 1.01 & 0.43 \\
\hline Traffic facility land & 182.14 & 0.38 & 189.21 & 0.39 & 0.30 \\
\hline Water conservancy facility land & 7.67 & 0.02 & 13.19 & 0.03 & 5.54 \\
\hline Industrial and mining land & 52.91 & 0.11 & 60.27 & 0.13 & 1.07 \\
\hline Other construction land & 13.25 & 0.03 & 22.08 & 0.05 & 5.13 \\
\hline
\end{tabular}

* Refers to the proportion of the total area of the LNNR.

Traffic facility land

Residential land

Other construction land

Figure 2 The distribution of landscape use types in the LNNR in 2006 and 2019
Industrial and mining land

Woodland

Water conservancy facility land

Water

Cultivated land

Grassland
Bare land

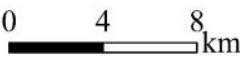


Between 2006 and 2019, the area of protected landscape types such as natural forest, shrub forest, grassland, and river water surface in the LNNR decreased. The conversion of protected landscapes was mainly

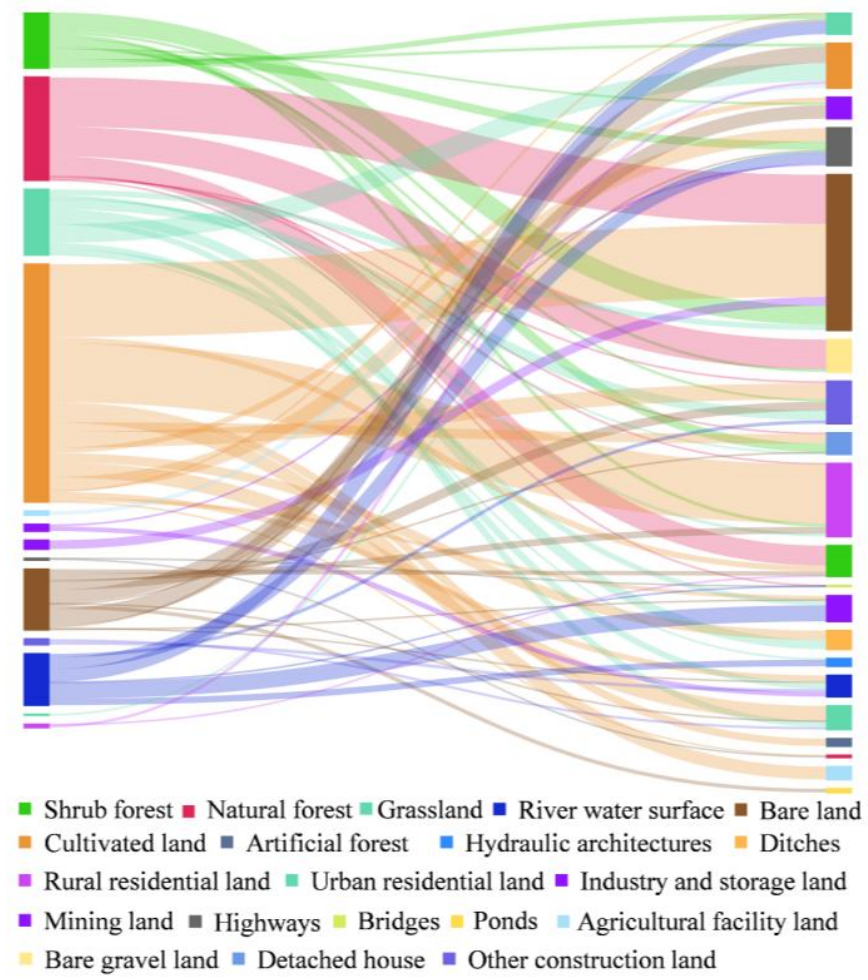

Figure 3 Landscape transformation Sanky map from 2006 to 2019 in the form of area conversions out. As shown in the landscape transfer matrix (Table 6) and the landscape transfer Sankey diagram (Figure 3), natural forest was mainly converted to bare land and bare gravel land with $11.41 \mathrm{hm}^{2}$ and $6.86 \mathrm{hm}^{2}$, corresponding to proportions of $47.96 \%$ and 28.84\%, respectively. Shrub forest was mainly converted to bare land and detached houses, with conversion areas of $4.40 \mathrm{hm}^{2}$ and $1.99 \mathrm{hm}^{2}$, corresponding to proportions of $34.24 \%$ and $15.49 \%$, respectively. Grasslands were mainly converted to cultivated land and ditches, with conversion areas of $4.29 \mathrm{hm}^{2}$ and $2.19 \mathrm{hm}^{2}$, corresponding to proportions of $28.32 \%$ and $14.46 \%$, respectively. River water surface was mainly converted to hydraulic architecture, mining land, and highways, with conversion areas of $1.49 \mathrm{hm}^{2}, 3.72 \mathrm{hm}^{2}$, and $2.69 \mathrm{hm}^{2}$, corresponding to proportions of $12.58 \%$, $31.42 \%$, and $22.72 \%$, respectively.

Additionally, between 2006 and 2019, the area of cultivated land in the interfered landscape in the LNNR decreased significantly. This cultivated land was mainly converted to bare land and rural residential land, with conversion areas of $16.84 \mathrm{hm}^{2}$ and $13.7 \mathrm{hm}^{2}$ and conversion rates of $30.63 \%$ and $24.92 \%$, respectively. Furthermore, the areas of other types of interfered landscape, such as industry and storage land, hydraulic architecture, and highways, all increased to varying degrees. The industry and storage land in the protected area are ore processing workshops or ore dumps, which have mainly been converted from bare land, with a conversion area of $3.11 \mathrm{hm}^{2}$ and a proportion of $63.34 \%$. The hydraulic architecture land is mainly used for dams or power stations, and has mainly been converted from river water surface, with a conversion area of $1.49 \mathrm{hm}^{2}$ and a transfer ratio of $85.14 \%$. Highways were mainly converted from cultivated land and river water surface, with a conversion area of $3.16 \mathrm{hm}^{2}$ and $2.69 \mathrm{hm}^{2}$, accounting for $36.36 \%$ and $30.96 \%$, respectively.

Moreover, the areas of the two types of neutral landscape, bare land and bare gravel land, increased 
significantly between 2006 and 2019, with bare land mainly being converted from natural forest and cultivated land, with conversion areas of $11.41 \mathrm{hm}^{2}$ and $16.84 \mathrm{hm}^{2}$, accounting for $31.72 \%$ and $46.82 \%$, respectively. The bare gravel land is mostly distributed in the rocky hills on the west bank of the Datong River, and the main source of transfer is from natural forest, with a transferred area of $6.86 \mathrm{hm}^{2}$, corresponding to a conversion rate of $91.34 \%$

The calculated LTI of the LNNR is -0.14 , indicating that the landscape of the reserve tended to deteriorate in general during 2006-2019.

\section{Analysis of landscape transformation under different drivers}

Between 2006 and 2019, the total area of changed landscape patches was $135.43 \mathrm{hm}^{2}$ and the total number of changed patches was 291 (Table 5). Seven of the nine driving factors were found to contribute negatively

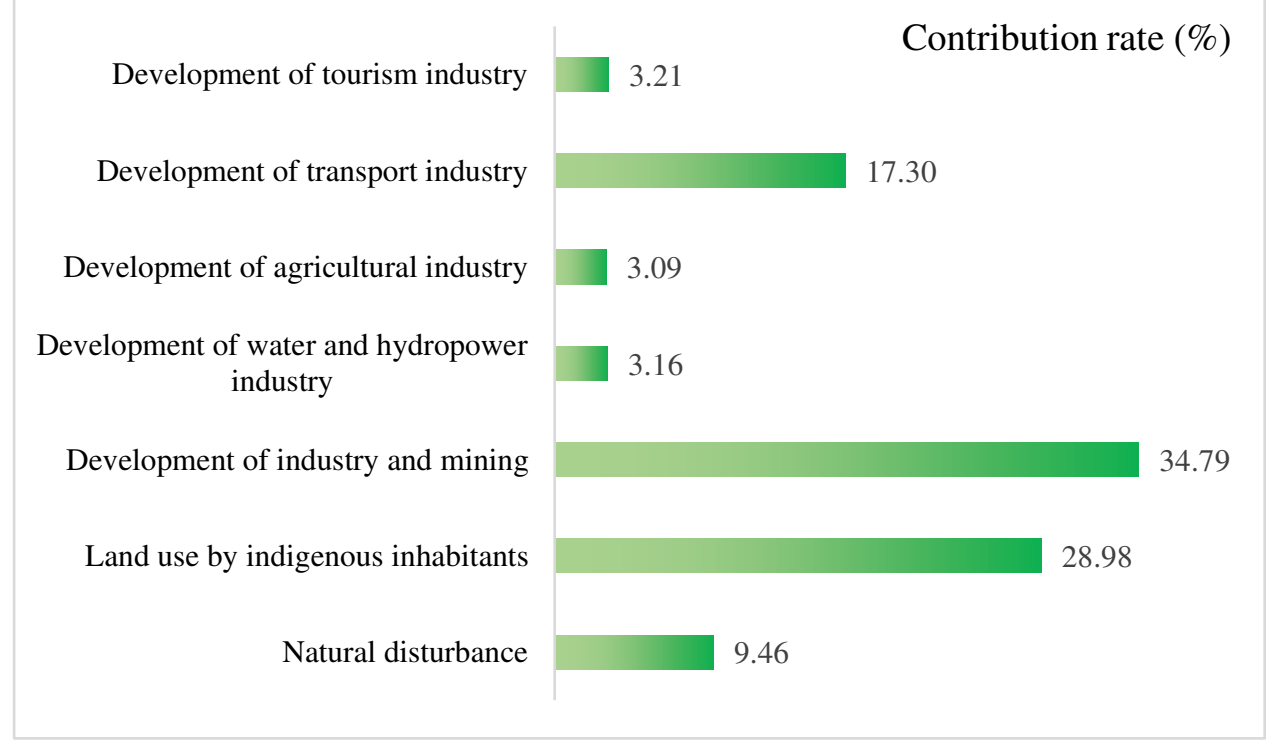

Figure 4 The contribution rate of different driving factors to the LTI to the LTI (Figure 4), among which the absolute values of the LTI caused by the development of industry and mining, land use by indigenous inhabitants, and the development of the transportation industry were the highest, with contributions of $34.79 \%, 28.98$, and $17.30 \%$, respectively. With socio-

economic development and population increase, the demand for construction land increased, and the number of landscape change patches caused by land use by indigenous inhabitants was the largest (135), with a total area of $37.8 \mathrm{hm}^{2}$. Land use by indigenous inhabitants was the largest driving factor of landscape area change and was also one of the main causes of the LTI decrease. In the experimental zone in the south of the reserve, there are large state-owned industrial and mining enterprises with a complete production line of ore mining, stockpiling, and processing built in the 1970s; this has caused some of the natural forest, shrub forest and water in the experimental zone of the reserve to degenerate into bare land or industry and storage land. The development of industry and mining has been the main driving factor for landscape deterioration in the reserve. There are $77 \mathrm{~km}$ of roads in the LNNR; the main transportation road in the reserve is provincial highway S301, which passes through the central experimental zone of the reserve, following the Datong River. From 2006 to 2019, $3.8 \mathrm{~km}$ of road reconstruction and expansion was carried out in the LNNR, mainly focusing on the 
provincial highway S301, which transformed part of the shrub forest, water, and cultivated land along the Datong River into transportation land. Additionally, there are four hydropower stations in the reserve, all of which are located in the reserve's experimental zone; of these, two were newly built, and one was expanded, between 2006 and 2019. Water facility land is the landscape type that experienced the fastest change in LNNR during this period. However, the contribution of the development of the hydropower industry to the LTI decrease is insignificant (3.16\%). This can be attributed to the fact that the construction of hydropower plants led to the conversion of protected landscapes (e.g., river water surface) into construction land, however, it also increased the water level, and consequently, patches with low assigned ecological levels along rivers (e.g., bare land and arable land) were converted into water lands, which have a higher assigned ecological level.

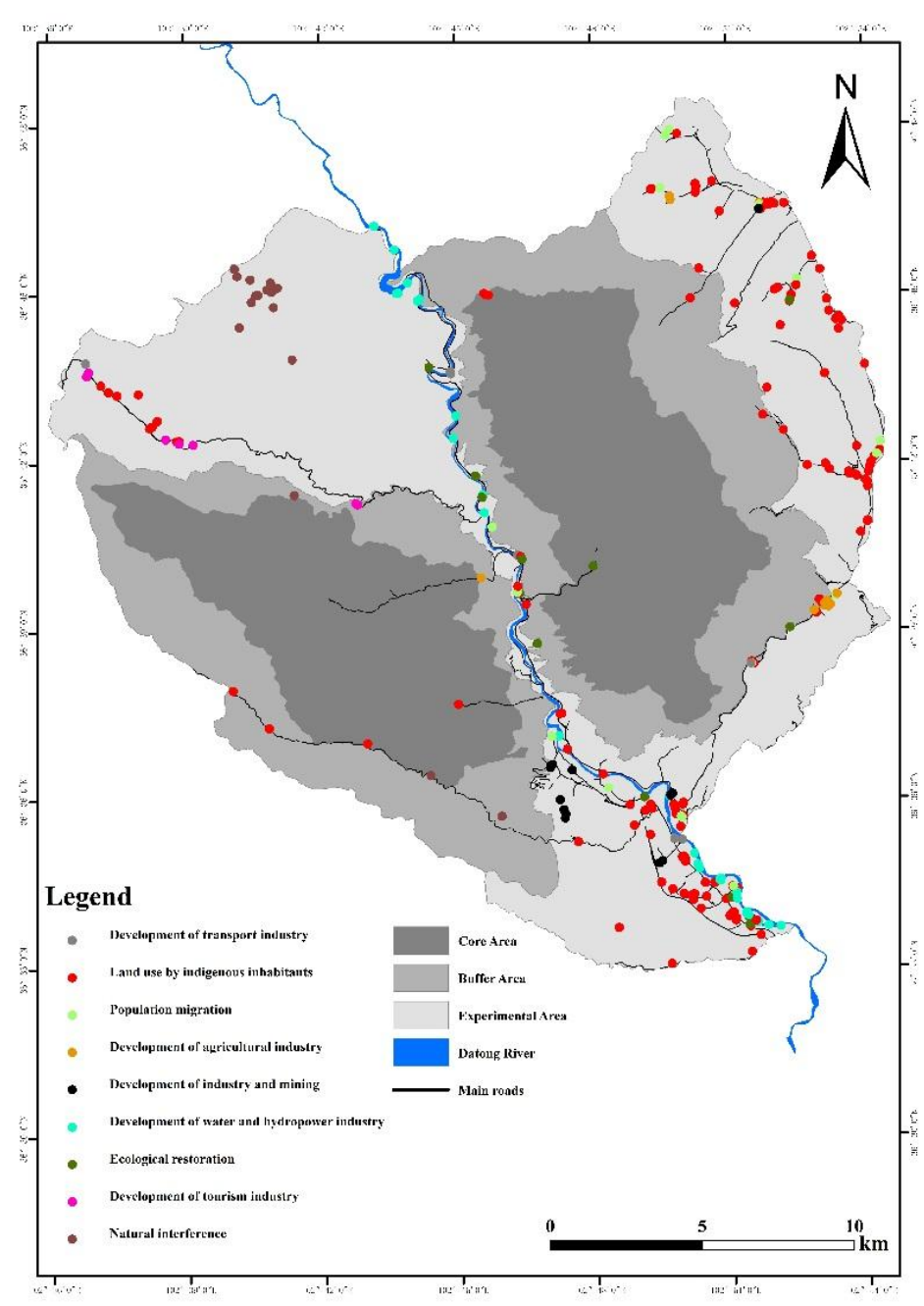

Figure 5 Spatial distribution of landscape change patches under different driving factors

Between 2006 and 2019, the LTI caused by population displacement and ecological restoration are positive, being $14.61 \times 10^{-3}$ and $12.37 \times 10^{-3}$, respectively. The landscape change due to population displacement was mostly a shift from interfered to neutral landscape and did not prod uce a significant improvement in landscape quality. Although ecological restoration led to a significant improvement in landscape quality, the area of implementation is small. Therefore, the population displacement and the ecological restoration were not sufficient to compensate for the overall trend of poorer landscape quality due to other drivers.

Table 5 Values of the Landscape Transfer Index (LTI) under different driving factors

\begin{tabular}{cccc}
\hline Driving factor & Patch area & Number of patches & \multicolumn{2}{c}{ Landscape transfer index $\left(\times \mathbf{1 0}^{-}\right.$} \\
$\left(\mathbf{h m}^{\mathbf{2}}\right)$ & 7.67 & 17 & -15.40 \\
\hline Natural disturbance & 37.80 & 135 & -47.17 \\
Land use by indigenous inhabitants & 18.47 & 16 & 14.61 \\
Population displacement & 26.45 & 28 & -56.63
\end{tabular}




\begin{tabular}{|c|c|c|c|}
\hline Development of water and hydropower industry & 15.07 & 27 & -5.14 \\
\hline Development of agricultural industry & 7.03 & 11 & -5.03 \\
\hline Development of transport industry & 13.25 & 33 & -28.17 \\
\hline Development of tourism industry & 2.68 & 9 & -5.22 \\
\hline Ecological restoration & 7.02 & 15 & 12.37 \\
\hline
\end{tabular}




\begin{tabular}{|c|c|c|c|c|c|c|c|c|c|c|c|c|c|c|c|c|c|c|c|c|c|}
\hline \multirow[b]{2}{*}{ 2006-2019 } & \multirow[b]{2}{*}{1} & \multirow[b]{2}{*}{2} & \multirow[b]{2}{*}{3} & \multirow[b]{2}{*}{4} & & & & & & & & & & & & & & & & \multicolumn{2}{|c|}{ Unit: $\mathrm{hm}^{2}$} \\
\hline & & & & & 5 & 6 & 7 & 8 & 9 & 10 & 11 & 12 & 13 & 14 & 15 & 16 & 17 & 18 & 19 & 20 & 21 \\
\hline 1 & & & & 1.32 & 0.69 & & & 0.54 & 1.96 & & & 4.4 & 0.65 & 0.55 & & & & & & 1.99 & 0.75 \\
\hline \multicolumn{22}{|l|}{2} \\
\hline 3 & 4.59 & & & & & & & & & 0.03 & & 11.41 & 6.86 & 0.46 & & & & & & 0.28 & 0.16 \\
\hline 4 & & & & & 4.29 & & 1.18 & & & & & 1.3 & & 2.23 & 2.19 & 0.26 & 1.36 & & 1.33 & 0.33 & 0.68 \\
\hline 5 & 1.35 & 1.69 & 0.11 & 0.23 & & 2.96 & 0.9 & 1.26 & 3.16 & & & 16.84 & & 3.7 & 2.13 & & 1.31 & & 3.44 & 2.19 & 13.7 \\
\hline 6 & & & & & 0.91 & & & & & & & & & & & & & & & & \\
\hline 7 & & & & & & & & & 0.45 & & & & & & & & 1.08 & & & & \\
\hline 8 & & & & & & & & & & & & 2.02 & & & & & & & & & \\
\hline 9 & & & 0.35 & & & & & & & 0.01 & & & & & & & & & & & \\
\hline \multicolumn{22}{|l|}{10} \\
\hline \multicolumn{22}{|l|}{11} \\
\hline 12 & 1.01 & & & 0.48 & 3.83 & & 0.11 & 3.11 & 0.27 & & & & & 2.06 & & & 0.42 & 0.88 & 0.11 & 0.14 & 1.57 \\
\hline \multicolumn{22}{|l|}{13} \\
\hline 14 & & & & & & & & & & & & & & & & & 0.73 & & 0.56 & & \\
\hline \multicolumn{22}{|l|}{15} \\
\hline \multicolumn{22}{|l|}{16} \\
\hline 17 & & & & 2.98 & & & 3.72 & & 2.69 & 0.18 & & & & 0.78 & & 1.49 & & & & & \\
\hline \multicolumn{22}{|l|}{18} \\
\hline 19 & & & & & & & & & 0.16 & & & & & & & & & & & & \\
\hline \multicolumn{22}{|l|}{20} \\
\hline 21 & 0.1 & & & & 0.61 & & & & & & & & & & & & & & & & \\
\hline
\end{tabular}

*Note: 1- Shrub forest; 2-Artificial forest; 3- Natural forest; 4- Grassland; 5- Cultivated land; 6- Agricultural facility land; 7- Mining land; 8- Industry and storage land; 9- Highways; 10- Bridges; 11- Railway land; 12- Bare land; 13- Bare gravel land; 14- Other construction land; 15- Ditches; 16- Hydraulic architecture; 17- River water surface; 18- Ponds; 19- Urban residential land; 20 Detached houses; 21- Rural

residential land.

Table 6 The area transfer matrix of second-level landscape types in the LNNR between 2006 and 2019 
Table 7 The area transfer-out ratio of second-level landscape types in the LNNR between 2006 and 2019

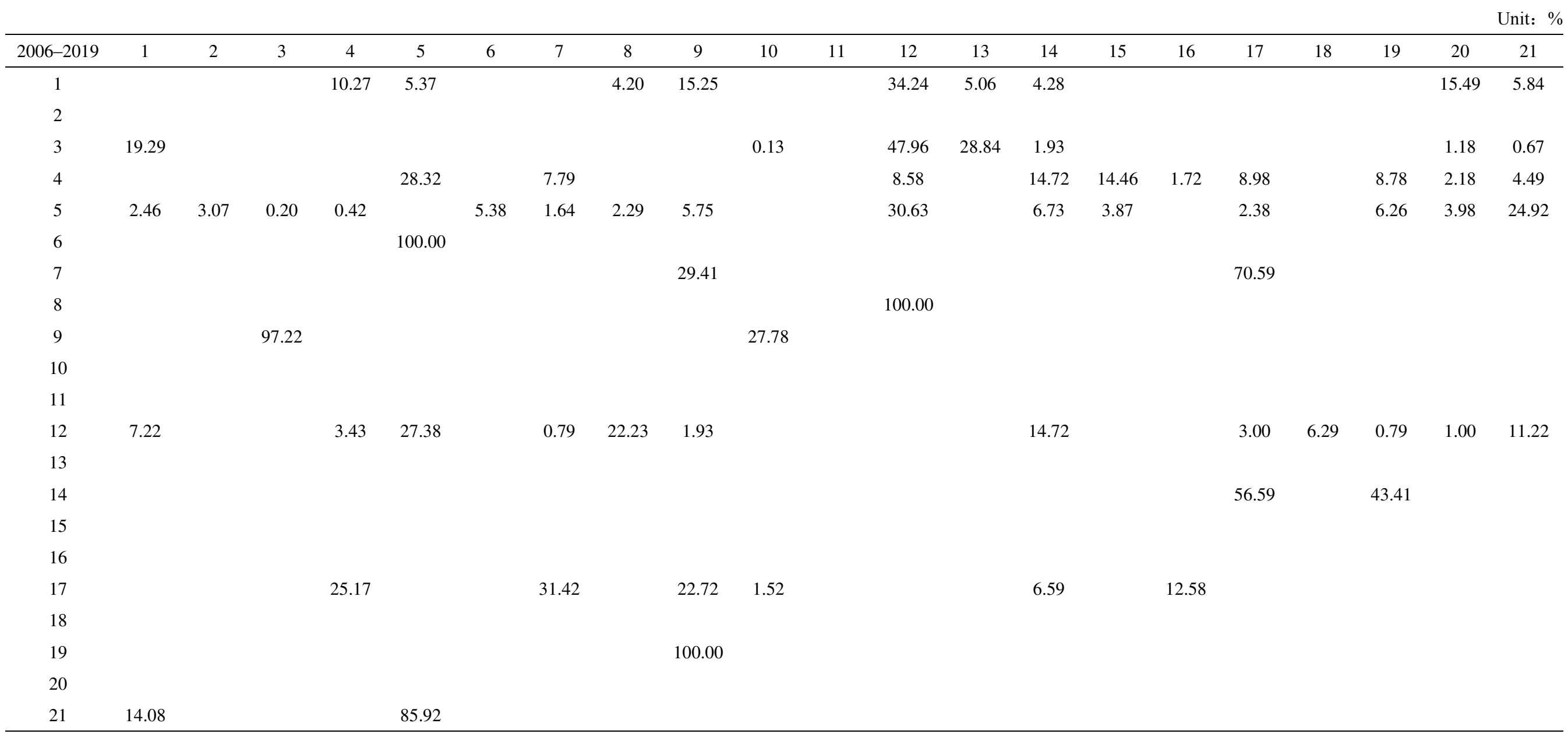

*Note: Numbers refer to the same landscape types as in Table 6 . 
Table 8 The area transfer-in ratio of second-level landscape types in the LNNR between 2006 and 2019

\begin{tabular}{|c|c|c|c|c|c|c|c|c|c|c|c|c|c|c|c|c|c|c|c|c|c|}
\hline 2006-2019 & 1 & 2 & 3 & 4 & 5 & 6 & 7 & 8 & 9 & 10 & 11 & 12 & 13 & 14 & 15 & 16 & 17 & 18 & 19 & 20 & 21 \\
\hline 1 & & & 65.11 & & 19.15 & & & & & & & 14.33 & & & & & & & & & 1.42 \\
\hline 2 & & & & & 100.00 & & & & & & & & & & & & & & & & \\
\hline 3 & & & & & 23.91 & & & & 76.09 & & & & & & & & & & & & \\
\hline 4 & 26.35 & & & & 4.59 & & & & & & & 9.58 & & & & & 59.48 & & & & \\
\hline 5 & 6.68 & & & 41.53 & & 8.81 & & & & & & 37.08 & & & & & & & & & 5.91 \\
\hline 6 & & & & & 100.00 & & & & & & & & & & & & & & & & \\
\hline 7 & & & & 19.97 & 15.23 & & & & & & & 1.86 & & & & & 62.94 & & & & \\
\hline 8 & 11.00 & & & & 25.66 & & & & & & & 63.34 & & & & & & & & & \\
\hline 9 & 22.55 & & & & 36.36 & & 5.18 & & & & & 3.11 & & & & & 30.96 & & 1.84 & & \\
\hline 10 & & & 13.64 & & & & & & 4.55 & & & & & & & & 81.82 & & & & \\
\hline \multicolumn{22}{|l|}{11} \\
\hline 12 & 12.23 & & 31.72 & 3.61 & 46.82 & & & 5.62 & & & & & & & & & & & & & \\
\hline 13 & 8.66 & & 91.34 & & & & & & & & & & & & & & & & & & \\
\hline 14 & 5.62 & & 4.70 & 22.80 & 37.83 & & & & & & & 21.06 & & & & & 7.98 & & & & \\
\hline 15 & & & & 50.69 & 49.31 & & & & & & & & & & & & & & & & \\
\hline 16 & & & & 14.86 & & & & & & & & & & & & & 85.14 & & & & \\
\hline 17 & & & & 27.76 & 26.73 & & 22.04 & & & & & 8.57 & & 14.90 & & & & & & & \\
\hline 18 & & & & & & & & & & & & 100.00 & & & & & & & & & \\
\hline 19 & & & & 24.45 & 63.24 & & & & & & & 2.02 & & 10.29 & & & & & & & \\
\hline 20 & 40.37 & & 5.68 & 6.69 & 44.42 & & & & & & & 2.84 & & & & & & & & & \\
\hline 21 & 4.45 & & 0.95 & 4.03 & 81.26 & & & & & & & 9.31 & & & & & & & & & \\
\hline
\end{tabular}

*Note: Numbers refer to the same landscape types as in Table 6 . 


\section{Protected landscape integrity}

The PLII of the LNNR decreased significantly between 2006 and 2019, from 82.7 to 68.7, indicating that the integrity of the protected landscape of the LNNR decreased significantly during this period.

Between 2006 and 2019, the total area of the protected landscape mosaic in the LNNR decreased by $44.58 \mathrm{hm}^{2}(0.12 \%)$, from $42,505.59 \mathrm{hm}^{2}$ to $42,456.16 \mathrm{hm}^{2}$ (Table 9); additionally, the number of patches increased from 109 to 128 , the fragmentation index increased significantly, from 0.22 to 0.57 , and the edge effect index decreased slightly, from 1.18 to 1.15 , indicating that the fragmentation of the protected landscape mosaic was the main reason for the reduced integrity of the protected landscape in the LNNR between 2006 and 2019. The main road network of the LNNR comprises the S301 provincial highway, in the central part of the experimental zone of the LNNR, the X137 county road, in the east of the LNNR, and a tourist road in the west of the Tulugou National Forest Park. In 2006, some road sections were narrow and not hardened, and did not form a sufficiently resistant surface, and therefore the protected landscape mosaic was not spatially completely cut away. Between 2006 and 2019, the reconstruction and expansion of roads resulted in a significant increase in the fragmentation of the protected landscape mosaic and a significant decrease in the landscape connectivity.

Table 9 A comparison of the landscape pattern indexes of protected landscape mosaics in the LNNR between 2006 and 2019

\begin{tabular}{ccccccc}
\hline Year & $\begin{array}{c}\text { Total Area } \\
\left(\mathrm{hm}^{2}\right)\end{array}$ & $\begin{array}{c}\text { Number of } \\
\text { Patches }\end{array}$ & $\begin{array}{c}\text { Fragmentation } \\
\text { Index }\end{array}$ & $\begin{array}{c}\text { Edge effect } \\
\text { Index }\end{array}$ & $\begin{array}{c}\text { Connectivity } \\
\text { Index }\end{array}$ & PLII \\
\hline 2006 & $42,505.59$ & 109 & 0.22 & 1.18 & 2.74 & 82.7 \\
2019 & $42,456.16$ & 128 & 0.57 & 1.15 & 2.61 & 68.7 \\
\hline
\end{tabular}

Note: PLII: Protected Landscape Integrity Index.

\section{Interfered landscape sprawl}

The ILSI of the LNNR was 26.61 and 26.68 in 2006 and 2019, respectively. The small change in the index over the study period indicates that the scope of influence of interfered landscape in the LNNR did not change significantly.

Between 2006 and 2019, the total area of interfered landscape in the LNNR increased by $20.35 \mathrm{hm}^{2}$ $(0.05 \%)$, from $5526.36 \mathrm{hm}^{2}$ to $5546.71 \mathrm{hm}^{2}$, with an area conversion rate of $0.37 \%$; additionally, the number of interfered landscape mosaic patches increased from 116 to 131 (Table 10). The degree of dispersion of the spatial distribution of the interfered landscape changed very little, and the increase in area occurred mostly in areas where there was originally a high concentration of interfered landscape; furthermore, the new patches were mostly small, which suggests that the control of the scope of influence of anthropogenic interference in 
the protected area of the LNNR was effective.

Table 10 A comparison of the Interfered Landscape Sprawl Index in the LNNR between 2006 and 2019

Year Total Area $\left(\mathrm{hm}^{2}\right) \quad$ Area ratio Number of Patches $\quad$ ILSI

\begin{tabular}{lllll}
\hline 2006 & 5526.36 & $11.47 \%$ & 116 & 26.61 \\
2019 & 5546.71 & $11.52 \%$ & 131 & 26.68 \\
\hline
\end{tabular}

370 Note: ILSI: Interfered Landscape Sprawl Index. 


\section{Discussion}

From 2006 to 2019, the area of protected landscape in the LNNR decreased and the area of interfered landscape increased; that is, the landscape in the reserve generally tended to deteriorate and the conservation effectiveness of the reserve was not significant. The implementation of major national natural forest resource protection projects promotes the development of natural ecosystems. In the LNNR, most of the protection project tasks were completed before the reserve was promoted to a national nature reserve in 2005, such as the natural forest protection projects, natural forest logging has been forbidden since 1998. Additionally, 446 $\mathrm{hm}^{2}$ of sparse forest land and shrubbery land in the reserve were afforested between 1998 and 2005. From 2001 to 2005, a reforestation project of $703.5 \mathrm{hm}^{2}$ was completed in the eastern experimental zone of the reserve. Unfortunately, we do not have access to high-resolution remote sensing image data from the early days of the reserve to analyze the landscape changes resulting from these effective conservation measures. By 2005 (when the reserve was promoted to a national nature reserve), the proportion of forest landscape in the LNNR had already reached $85.8 \%$, and subsequently, the implementation of various protection projects in the reserve mainly focused on hill closure for forestation. The decline in landscape quality that took place in the LNNR between 2006 and 2019 was mainly due to three reasons. First, there are large industrial and mining enterprises in the reserve, whose activities can cause great damage to the ecological environment (Dong 2008). In 2017, all of the mining enterprises in the LNNR stopped ore mining activities and jointly formulated a "mine vegetation restoration plan" together with the nature reserve management; this plan was implemented by 2018 , however, ecological restoration is expected to take some time (Li 2004), and the effectiveness of vegetation restoration is not yet clear. Secondly, activities by indigenous residents, such as agricultural reclamation, settlement construction, and resource development have led to a reduction in the quality of the natural ecosystem in the LNNR (Mette 2014; Chen 2016; Cao et al. 2019). There are large numbers of indigenous residents in the LNNR, and these residents have a relatively concentrated distribution, mainly in the Liancheng town government seat in the southern part of the experimental zone and the Minle Township administrative villages at the eastern edge of the experimental zone. The frequent anthropogenic activities in the LNNR have placed great pressure on the protection and management of the reserve and have become an important reason for the decline of the overall quality of its landscape. Thirdly, the increase in population in the protected area of the LNNR has led to an increase in transport demand, and road construction has inevitably encroached on trees, shrubs, and water, resulting in a deterioration of landscape quality. Most of the PAs in China have a certain degree of human interference because of rapid population growth during the past few 
decades. However, the current management and protection strategies for PAs are not effective. Therefore, in PAs where habitat quality is declining, diverse ecological restoration projects should be selected, while for PAs that do not have conservation value, management measures should be adjusted in a timely manner to avoid further expansion of the scope and extent of interference.

The PLII can comprehensively reflect the degree of fragmentation, edge effect intensity, and spatial connectivity of wildlife habitats in PAs. This study uses changes in this index to evaluate the effectiveness of the protection of the integrity of the protected landscape in the LNNR. To calculate the index, it is necessary to delineate the protected landscape mosaic according to the real situation in different nature reserves. This is mainly achieved in two ways: First, it is possible to delineate the protected landscape mosaic according to the ecosystem type and protected objects of a specific protected area. For example, in this study, protected landscape types with a ecological level $\geq 0.38$ were combined into a protected landscape mosaic, which included artificial woodland. Meanwhile, related studies showed that in the Wanglang National Nature Reserve, where giant pandas are the main protection object, artificial woodland is not a suitable habitat for the pandas (Yang et al. 2013). Second, when calculating the PLII, the interfered landscape which have not caused protected landscape separation can be merged into the protected landscape mosaic for analysis. For example, previous studies considered that transportation land types such as Class IV roads, forest roads, and rural roads do not form a substantial separation to protected landscape patches (Cui et al. 2018). Additionally, to ensure the accuracy of the calculation results, the protected landscape mosaic can be further integrated according to the distribution dynamic of protected objects. In summary, the PLII can be used to evaluate the integrity of protected landscapes, and its change value can be employed to assess the effectiveness of PAs for protecting major conservation objects and their habitats.

The ILSI directly reflects the spatial spread of interfered landscape, and this study uses changes in this index to evaluate changes in the effect of anthropogenic interference in the LNNR. For example, in this study, landscape types with an assigned ecological level $\leq-0.38$ were combined into an interfered landscape mosaic, which includes cultivated land. A previous study showed that in Hanzhong, Shaanxi Province, cultivated land (paddy fields) is an important habitat for the crested ibis (Nipponia nippon) and green rice cultivation is thus of great significance to the conservation of this species (Liu et al. 2014). The interfered landscape mosaic can be adjusted according to the main object of protection and its sensitivity to various types of interference, and the ILSI can therefore be universally applied to evaluate and control the spread of human interference.

Based on the results of this study, we give the following recommendations to promote the protection effectiveness of protected areas: (1) Adjust the scope of PAs and functional areas as soon as possible, mainly 
by removing areas without protection value (e.g., towns, industrial and mining enterprises, and water conservancy and hydropower facilities) from PAs to avoid the interference of these areas in the assessment of the effectiveness of the landscape protection of PAs. Furthermore, for interfered landscape that cannot be withdrawn from the scope of PAs, scientific monitoring should be conducted to minimize the negative impact of this landscape on the main protection objects of nature reserves and their habitats; (2) Carry out the strict control and environmental impact assessment of the construction of facilities such as roads and hydropower stations in PAs to prevent the increased fragmentation of the protected landscape. At the same time, construct a protected area habitat corridor system to mitigate the decline in the connectivity and integrity of the protected landscape; and (3) obey the National Nature Reserve Regulation of China, follow the management routines of the LNNR strictly, and construct monitoring and response systems to the long-term management issues.

\section{Conclusion}

Using high-resolution remote sensing image data, this study analyzed the landscape dynamics and its drivers in the LNNR since its promotion to a national-level reserve; specifically, it evaluated the landscape protection effectiveness of the LNNR from 2006 to 2019 using the Landscape Transfer Index, Protected Landscape Integrity Index, and Interfered Landscape Sprawl Index. The following conclusions can be drawn:

(1) From 2006 to 2019, the area of protected landscapes - namely woodland, grassland, and waterwithin the protected area of the LNNR decreased, while the area of interfered landscape-namely residential land, industrial and mining land, and water conservancy facility land - increased, resulting in a decrease in the overall quality of the landscape and an increase in the degree of human interference in the reserve. These changes were mostly concentrated in the experimental zone of the protected area of the LNNR, and the main causes of the overall deterioration of the landscape were industrial and mining exploitation, land use by indigenous inhabitants, and the construction of transportation facilities. Although these changes are not obvious, they still require attention and timely remedial measures.

(2) During the same period, there was a decline in the integrity of the protected landscape mosaic in the protected area of the LNNR. This decline was mainly due to landscape fragmentation caused by road expansion and modification in the experimental zone of the protected area. It is necessary to mitigate the decline in the integrity of the protected landscape of the reserve by constructing ecological corridors and performing ecological restoration.

(3) The spatial distribution of interfered landscape in the LNNR did not change significantly between 2006 and 2019. The area of interfered landscape increased mostly in areas where such landscape was originally 
concentrated, and the new patches were mostly small. These results suggest that the protected area of the LNNR is effective for controlling the scope of influence of human interference in the reserve.

This study proposes a comprehensive method for evaluating the landscape conservation effectiveness of PAs based on the LTI, the PLII, and the ILSI. This method has the potential to be applied to the rapid assessment of landscape conservation effectiveness in various types of protected area.

\section{Declarations}

\section{Abbreviations}

PAs: Protected Areas; LNNR: Liancheng National Nature Reserve; LTI: Landscape Transfer Index; PLII: Protected Landscape Integrity Index; ILSI: Interfered Landscape Sprawl Index.

\section{Acknowledgements}

We are grateful to Mingchang Shi, Yaomin Zheng, and Jiakai Liu for their help in data analysis. We also thank Fachun Hua, Zhihong Man, and many others from the administrative bureau of LNNR for their assistance during the field investigation.

\section{Authors' contributions}

Z.H. designed the study, data preparation, analysis, and wrote the paper. Y.P. participated in the field investigation and provided suggestions for the method. R.W. participated in the data preparation and processing. B.Z. and N.L. participated in the remote sensing image interpretation and the accuracy calculation of the interpretation results. G.C. provided the project design and performed paper editing. All the authors read and approved the final manuscript.

\section{Funding}

This study was supported by the National Key Research and Development Plan of China (2018YFC0507203).

\section{Availability of data and materials}

The datasets used and/or analyzed during the current study are available from the corresponding author on reasonable request.

\section{Ethics approval and consent to participate}

Not applicable.

\section{Consent for publication}

Not applicable.

\section{Competing interests}

The authors declare that they have no competing interests. 


\section{References}

B Guan, G Cui, Z Po (2012) A Review of Assessment of Wildlife Conservation Effectiveness in Nature Reserve. World Forestry Research 25: 40-45.

Broadbent E N, Zambrano A M A, Dirzo R, Durham W H, Driscoll L, Gallagher P, Salters R, Schultz J, Colmenares A, Randolph S G (2012) The effect of land use change and ecotourism on biodiversity: a case study of Manuel Antonio, Costa Rica, from 1985 to 2008. Landscape Ecology 27: 731-744. https://doi.org/10.1007/s10980-012-9722-7

C Wang (2019) Research Progress and Prospect of Ecological Protection and Development in Nature Reserves. Forestry Economics 41: 3-9. http://doi.org/10.13843/j.cnki.lyjj.2019.10.001

C Wei, H Lin, X Tong, W U Dan (2019) Effects of human activities on the ecosystems of China's National Nature Reserves. Acta Ecologica Sinica 39: 1338-1350. http://doi.org/10.5846/stxb201808251814

C Wenlian, G Li, L Shanwei, W Yanling (2014) Dynamic Change Analysis of Landscape Pattern in Laoshan Nature R eserve Based on High-resolution Satellite Images from 2003 to 2009. Acta Laser Biology Sinica 6: 614-619. http:// doi.org/10.3969/j.issn.1007-7146.2014.06.018

Cao W, Zhou S, Wu S (2015) Land-use regionalization based on landscape pattern indices using rough set theory and catastrophe progression method. Environmental Earth Sciences 73: 1611-1620. https://doi.org/10.1007/s12665-014-3511-3

Chase J M, Blowes S A, Knight T M, Gerstner K, May F (2020) Ecosystem decay exacerbates biodiversity loss with habitat loss. Nature 584: 238-243. https://doi.org/10.1038/s41586-020-2531-2

Chinese State Forestry Bureau (2008) Classification for land cover of nature reserve(LY/T 1725-2008). Standards press of China, Beijing.

Chinese State Forestry Bureau (2014) Technical guidelines for assessing conservation efficiency of nature reserves - Part 3:Landscape conservation(LY/T 2244.3-2014). Standards press of China, Beijing.

Community-based Conservation of Animal Species with Extremely Small Populations. Sichuan Journal of Zoology 33: 612-619. http://doi.org/10.3969/j.issn.1000-7083.2014.04.024.

Cong P, Chen K, Qu L, Han J (2019) Dynamic Changes in the Wetland Landscape Pattern of the Yellow River Delta from 1976 to 2016 Based on Satellite Data. Chinese Geographical Science 29: 372-381. https://doi.org/10.1007/s11769-019-1039-x

D Liu, C Wang, B Qing, H Ding, J Lu (2014) Thirty-years' Conservation of Crested Ibis Nipponia nippon in China: A Model for

Fuller R A, Mcdonald-Madden E, Wilson K A, Carwardine J, Grantham H S, Watson J E M, Klein C J, Green D C, Possingham H P (2010) Replacing underperforming protected areas achieves better conservation outcomes. Nature 466: $365-367$. https://doi.org/10.1038/nature09180

G Cui, Z Guo, Q Wang, S Xing, J Zhang (2018) Key technologies for the construction and management of nature reserve. China Forestry Publishing House,Beijing.

Guadilla-Sáez S, Pardo-De-Santayana M, Reyes-García V, Svenning J (2019) Biodiversity conservation effectiveness provided by a protection status in temperate forest commons of north Spain. Forest Ecology and Management 433: 656-666. https://doi.org/10.1016/j.foreco.2018.11.040

H Yang, D Kang, W Kang, J Li, J Li, L Zhao, X Wang (2013) Suitability of plantation recovery as the habitat of giant panda. Journal of Beijing Forestry University 35: 67-73. http://doi.org/10.13332/j.1000-1522.2013.04.021

He X, Bo Y, Du J, Li K, Wang H, Zhao Z (2019) Landscape pattern analysis based on GIS technology and index analysis. Cluster Computing 22: 5749-5762. https://doi.org/10.1007/s10586-017-1502-3

J Chen (2016) The dynamic change of ecological environment in nature reserves under the human disturbance-a case study of Huangchulin Nature Reserve in Xiongjiang. Fujian Normal University.

J Lin, X Liu (2019) Evaluation of the Management Effectiveness if Marine Protected Areas : A Brief Review of Recent Research Progress. Transactions of Oceanology and Limnology 3: 184-190. http://doi.org/10.13984/j.cnki.cn37-1141.2019.03.021

J Ma, K Rong, K Cheng (2012) Research and practice on biodiversity in situ conservation in China: progress and prospect. Biodiversity Science 20: 551-558. http://doi.org/10.3724/SP.J.1003.2012.08118

J Niu, X Yu, J Gao (2003) Landscape dynamics in Liangshui Nature Reserve, northeast China. Journal of Beijing Forestry University 25: 74-78.http://doi.org/10.3321/j.issn:1000-1522.2003.03.015 
JW Chen (2019) 70 years development of Nature Reserve System in China. Land Greening 307: 50-53.

L Fangzheng, Z Jianliang, W Liang, Y Zengwu, C Guofa (2016) Vegetation growth and conservation efficacy assessment in the Southern Part of the Gansu Anxi National Nature Reserve in Hyper-Arid Desert. Acta Ecologica Sinica 36: 1582-1590. http://doi.org/10.5846/stxb201408191645

L Xin, Y Jin, Y Zhu, J Luo, L Wang, B Chen, W Wang (2015) Development of Effectiveness Assessment Indicators of Desert Nature Reserve in China:A Case Study of the Anxi National Nature Reserve. Journal of Desert Research 35: 1693-1699. http://doi.org/10.7522/j.issn.1000-694X.2015.00075.

L Zexu, G Wenfeng, Y Li, L Hao (2014) Analysis of the Impacts of Landscape Dynamics and Human Disturbance on Red-Crowned Crane in Zhalong National Nature Reserve. Chinese Journal of Wildlife 35: 431-435. http://doi.org/10.3969/j.issn.10000127.2014.04.013

Li F, Altermatt F, Yang J, An S, Li A, Zhang X (2020) Human activities' fingerprint on multitrophic biodiversity and ecosystem functions across a major river catchment in China. Global Change Biology. https://doi.org/10.1111/gcb.15357

Lindenmayer Db F J(2006) Habitat fragmentation and landscape change. Island press ,Washington, D.C.

M Lin, T Lin, Q Qiu, C Sun, F Deng, G Zhang (2017) Comparition of ecological security stress effects of artificial landscapes on natural landscapes in different rapid urban sprawl areas. Chinese Journal of Applied Ecology 28: 1326-1336. http://doi.org/10.13287/j.1001-9332.201704.007

Maxwell S, Cazalis V, Dudley N, Hoffmann M, Rodrigues A S L, Stolton S, Visconti P, Woodley S, Maron M, Strassburg B, Wenger A, Jonas H, Venter O, Watson J (2020) Area-based conservation in the twenty-first century. Nature (London) 586: 217-227. https://doi.org/10.1038/s41586-020-2773-z

Mehring M, Stoll-Kleemann S (2011) How Effective is the Buffer Zone? Linking Institutional Processes with Satellite Images from a Case Study in the Lore Lindu Forest Biosphere Reserve, Indonesia. Ecology and Society 16. https://doi.org/10.5751/ES04349-160403

Mette V O P K (2014) Human-driven topographic effects on the distribution of forest in a flat, lowland agricultural region. Journal of geographical sciences 24: 76-92. https://doi.org/10.1007/s11442-014-1074-6

P Richard, H Liu, Y Yin (2011) Conservation of biodiversity under impact of human activities : Vegetation evolution in Central Europe and its implication. Chinese Journal of Ecology 30: 584-588. http://doi.org/10.13292/j .1000-4890.2011.0075

Rosas Y M, Peri P L, Huertas Herrera A, Pastore H, Martínez Pastur G (2017) Modeling of potential habitat suitability of Hippocamelus bisulcus: effectiveness of a protected areas network in Southern Patagonia. Ecological Processes 6. https://doi.org/10.1186/s13717-017-0096-2

Rovero F, Owen N, Jones T, Canteri E, Iemma A, Tattoni C (2017) Camera trapping surveys of forest mammal communities in the Eastern Arc Mountains reveal generalized habitat and human disturbance responses. Biodiversity and Conservation 26: 11031119. https://doi.org/10.1007/s10531-016-1288-2

S Xiaoyang, S Wenming, W Huawei, H Peng, L Gang (2016) Dynamic monitoring of Tibetan antelope habitat suitability in the Hoh Xil Nature Reserve using remote sensing images. Resources Science 38: 1434-1442. http://doi.org/10.18402/resci.2016.08.03 Sala O E, Chapin F R, Armesto J J, Berlow E, Bloomfield J, Dirzo R, Huber-Sanwald E, Huenneke L F, Jackson R B, Kinzig A, Leemans R, Lodge D M, Mooney H A, Oesterheld M, Poff N L, Sykes M T, Walker B H, Walker M, Wall D H (2000) Global biodiversity scenarios for the year 2100. Science 287: 1770-1774.https://doi.org/10.1126/science.287.5459.1770

Su C, Fu B, Lu Y, Lu N, Zeng Y, He A, Lamparski H (2011) Land use change and anthropogenic driving forces: A case study in Yanhe River Basin. Chinese Geographical Science 21: 587-599. https://doi.org/10.1007/s11769-011-0495-8

Tang Z, Fang J, Sun J, Gaston K J (2011) Effectiveness of protected areas in maintaining plant production. PLoS One 6: e19116.https://doi.org/10.1371/journal.pone.0019116

Wittemyer G, Elsen P, Bean W T, Burton A C O, Brashares J S (2008) Accelerated Human Population Growth at Prot ected Area Edges. Science (American Association for the Advancement of Science) 321: 123-126. https://doi.org/10. $1126 /$ science. 1158900

X Liu, Z Fu, R Wen, C Jin, X Wang, C Wang, R Xiao, P Hou (2020) Characteristics of human activities and the spa tio-temporalchanges of national nature reserves in China. Geographical Research 39: 2391-2402. http://doi.org/10.118 
21/dlyj020200458

Y Jin, J Luo, Y Zhu, L Xin, Z Diao, B Chen, W Wang (2015) Assessment of effectiveness of wetland conservation in Huihe National Nature Reserve in Inner Mongolia. Research of Environmental Sciences 28: 1424-1429. http://doi.o $\mathrm{rg} / 10.13198 / \mathrm{j}$. issn.1001-6929.2015.09.12.

Y Li, G Jiang (2004) Ecological restoration of mining wasteland in both China and abroad:an over review. Acta Ecologica Sinica 24: 95-100. http://doi.org/10.3321/j.issn:1000-0933.2004.01.015

Z Dong (2008) On the impact of mining on ecological environment. Forestry of China 12: 42.

Z Zhao, L Zhong, R Yang (2020) Discussion on the Nature Reserves as Foundation of Protected Areas in the New Era of Ecological Civilization. Chinese Landscape Architecture 36: 6-13. http://doi.org/10.19775/j.cla.2020.08.0006

Zhang J, Liu F, Cui G (2014) The efficacy of landscape-level conservation in Changbai Mountain Biosphere Reserve, China. PLoS One 9: e95081.https://doi.org/10.1371/journal.pone.0095081

Zheng X J, Sun P, Zhu W H, Xu Z, Fu J, Man W D, Li H L, Zhang J, Qin L (2017) Landscape dynamics and driving forces of wetlands in the Tumen River Basin of China over the past 50 years. Landscape and Ecological Engineering 13: 237-250. https://doi.org/10.1007/s11355-016-0304-8

ZL Guo,GF Cui, XP Wang, LS Na,YM Zheng, MY Zhang, LJ Cui (2017) Landscape dynamic and conservation efficiency in Ar Horqin National Nature Reserve,Inner Mongolia, China. Chinese Journal of Applied Ecology 28: 2649-2656. http://doi.org/10.13287/j.1001-9332.201708.028 

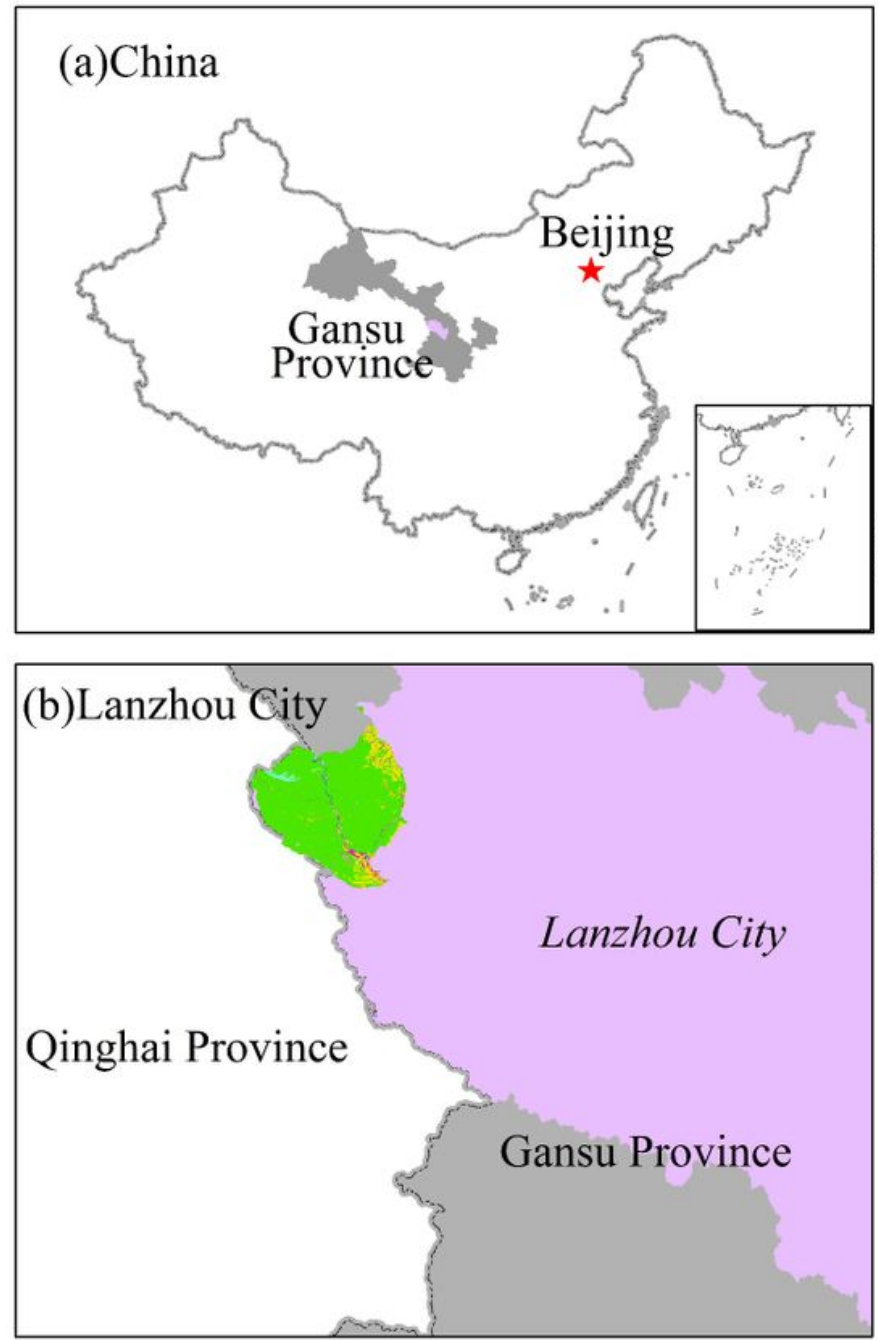

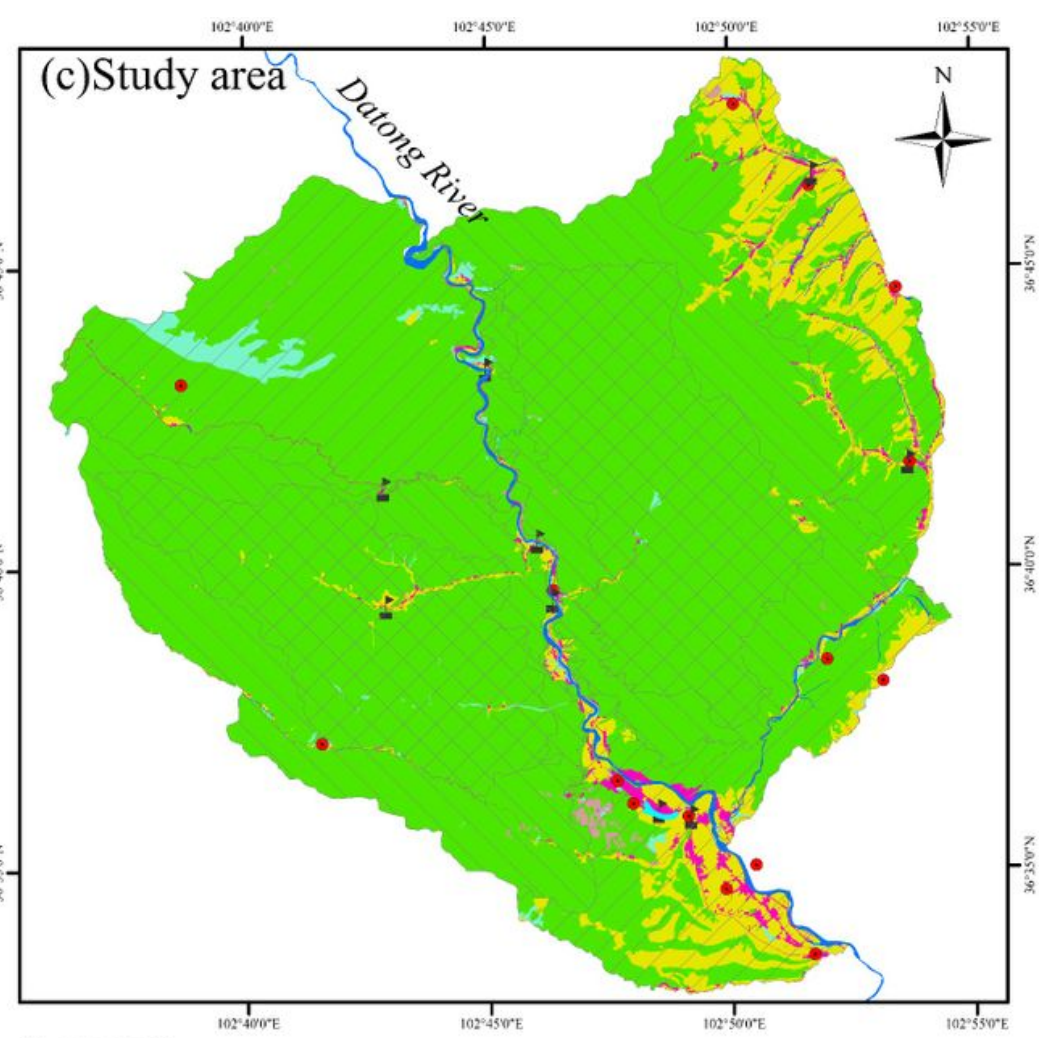

Legend

Core Zone Buffer Zone Experimental Zone

- Administrative village

- Protection Station

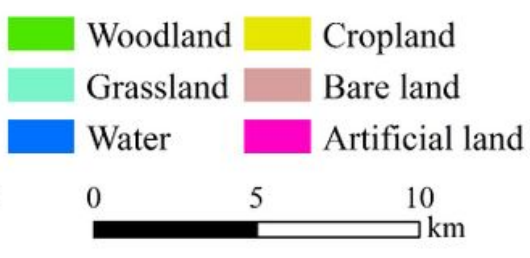

\section{Figure 1}

Location map of the Liancheng National Nature Reserve (LNNR). Note: The designations employed and the presentation of the material on this map do not imply the expression of any opinion whatsoever on the part of Research Square concerning the legal status of any country, territory, city or area or of its authorities, or concerning the delimitation of its frontiers or boundaries. This map has been provided by the authors. 

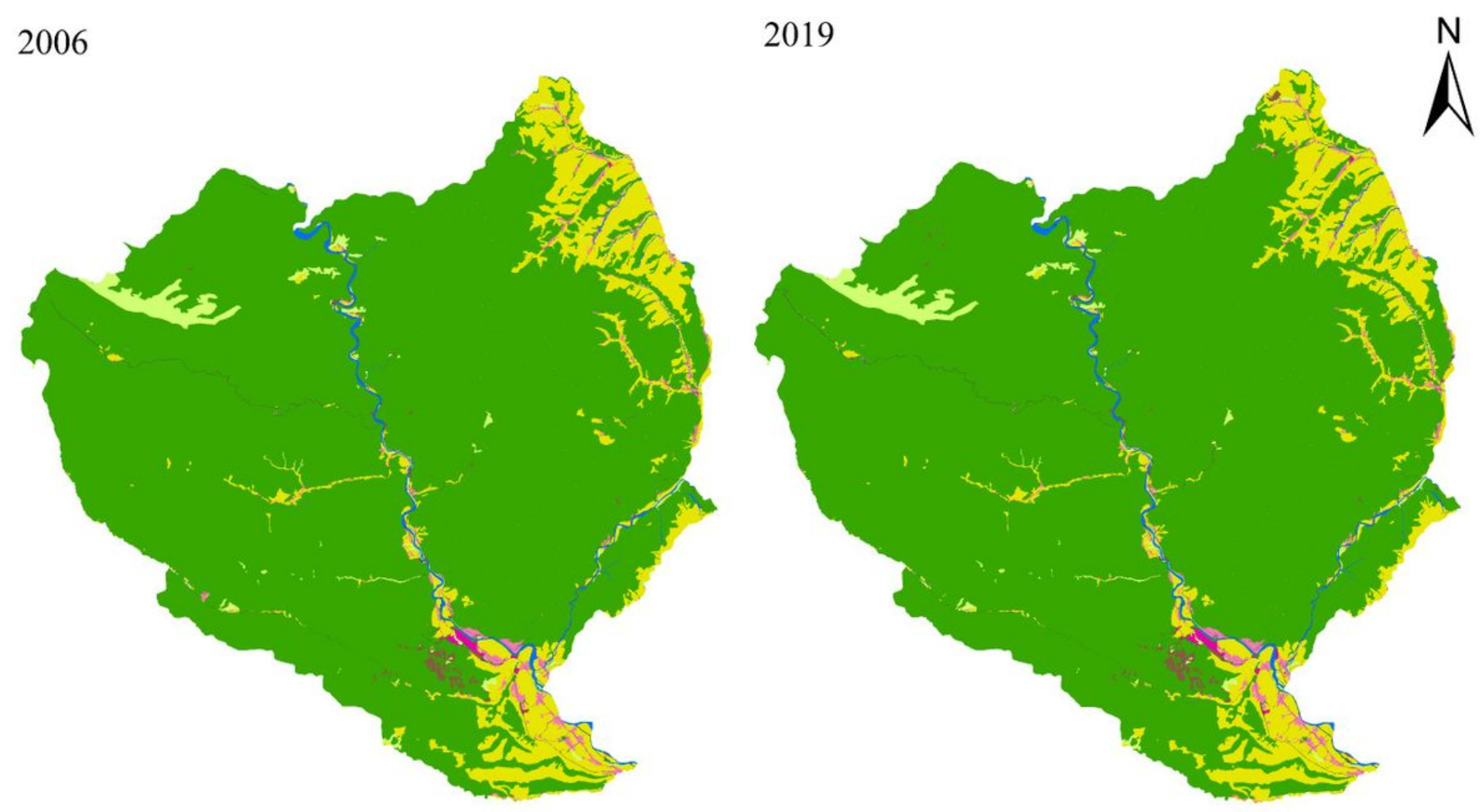

\section{Legend}

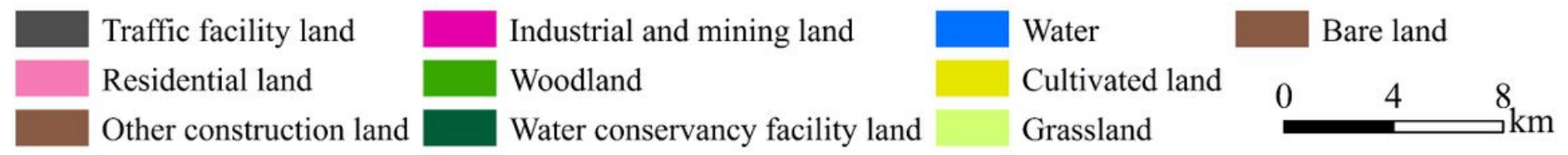

\section{Figure 2}

The distribution of landscape use types in the LNNR in 2006 and 2019. Note: The designations employed and the presentation of the material on this map do not imply the expression of any opinion whatsoever on the part of Research Square concerning the legal status of any country, territory, city or area or of its authorities, or concerning the delimitation of its frontiers or boundaries. This map has been provided by the authors. 


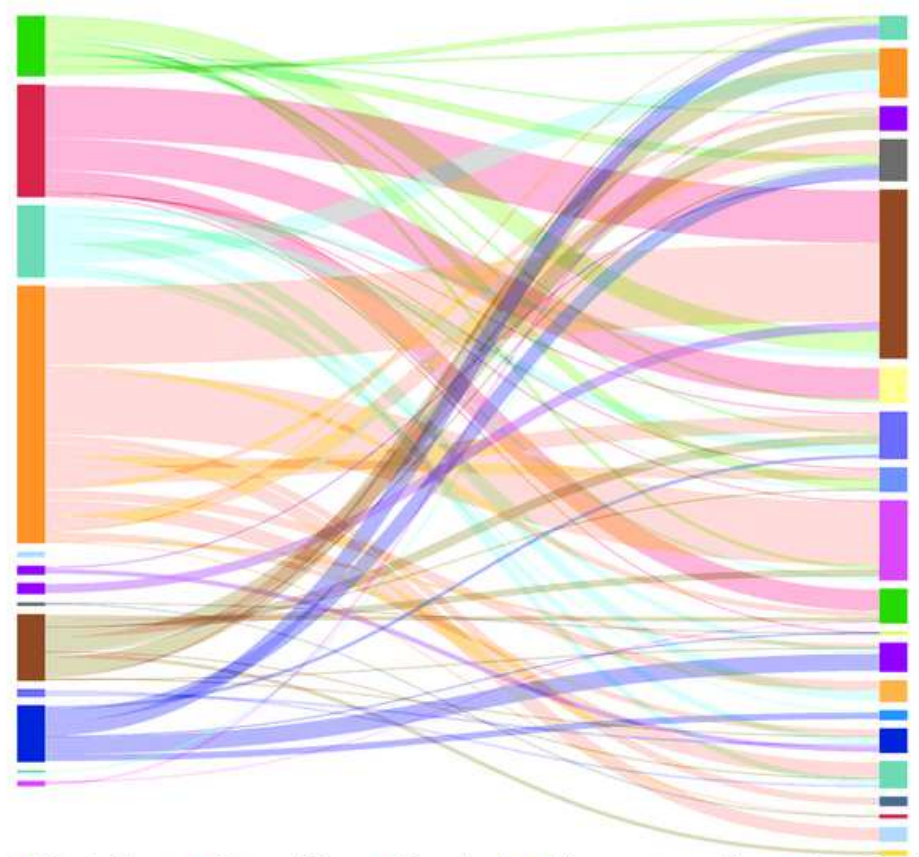

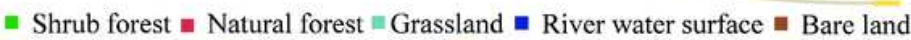

= Cultivated land $\equiv$ Artificial forest $=$ Hydraulic architectures $=$ Ditches

- Rural residential land $=$ Urban residential land $\mathbf{m}$ Industry and storage land

- Mining land $=$ Highways $=$ Bridges $=$ Ponds $=$ Agricultural facility land Bare gravel land $=$ Detached house $=$ Other construction land

\section{Figure 3}

Landscape transformation Sanky map from 2006 to 2019

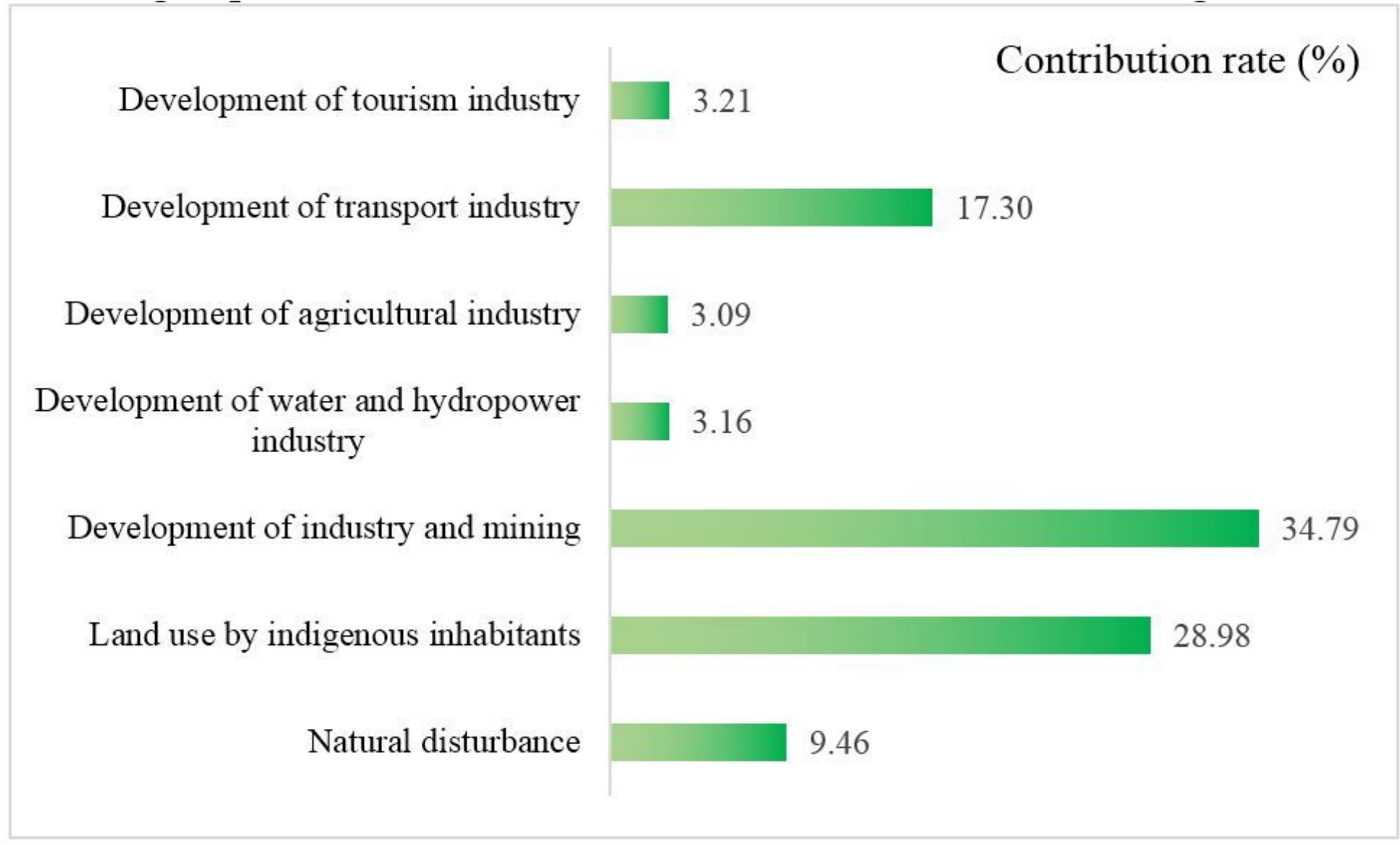


Figure 4

The contribution rate of different driving factors to the LTI

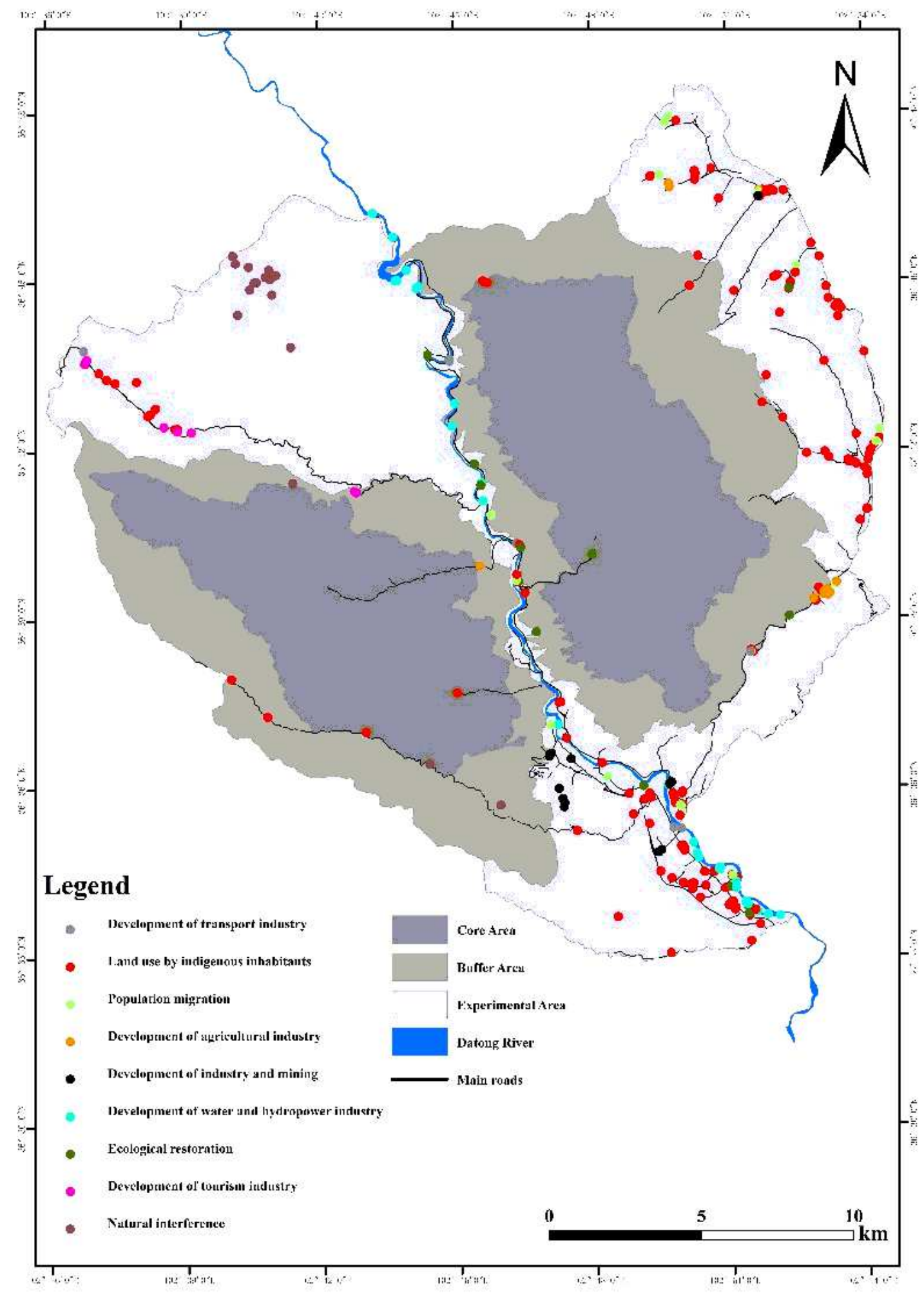

Figure 5

Spatial distribution of landscape change patches under different driving factors. Note: The designations employed and the presentation of the material on this map do not imply the expression of any opinion 
whatsoever on the part of Research Square concerning the legal status of any country, territory, city or area or of its authorities, or concerning the delimitation of its frontiers or boundaries. This map has been provided by the authors. 